\title{
Interpretive Structural Modelling and Fuzzy MICMAC Approaches for Customer Centric Beef Supply Chain: Application of a Big Data Technique
}

\author{
Nishikant Mishra' ${ }^{1}$, Akshit Singh ${ }^{2}$, Nripendra P. Rana ${ }^{3}$ and Yogesh K. Dwivedi ${ }^{4}$ \\ ${ }^{1}$ Hull University Business School, University of Hull, United Kingdom. Email: Mishra09@ gmail.com \\ ${ }^{2}$ Alliance Manchester Business School, University of Manchester, United Kingdom. \\ Email: Akshit.Singh@manchester.ac.uk \\ ${ }^{3}$ School of Management, Swansea University, United Kingdom. Email: nrananp@ gmail.com \\ ${ }^{4}$ School of Management, Swansea University, United Kingdom. Email: ykdwivedi@gmail.com
}

\begin{abstract}
The food retailers have to make their supply chains more customer driven to sustain in modern competitive environment. It is essential for them to assimilate consumer's perception to improve their market share. The firms usually utilise customer's opinion in the form of structured data collected from various means such as conducting market survey, customer interviews and market research to explore the interrelationships among factors influencing consumer purchasing behaviour and associated supply chain. However, there is abundance of unstructured consumer's opinion available on social media (Twitter). Usually, retailers struggle to employ unstructured data in above decision-making process. In this paper, firstly, by the help of literature and social media Big Data, factors influencing consumer's beef purchasing decisions are identified. Thereafter, interrelationships between these factors are established using big data supplemented with ISM and Fuzzy MICMAC analysis. Factors are divided as per their dependence and driving power. The proposed frameworks enable to enforce decree on the intricacy of the factors. Finally, recommendations are prescribed. The proposed approach will assist retailers to design consumer centric supply chain.
\end{abstract}

Keywords: Big Data, Interpretive Structural Modelling (ISM), Fuzzy MICMAC, Beef Supply Chain, Twitter

\section{Introduction}

The main objective of modern industry is to please consumers. Usually, supply chains are designed using customer driven approach. The businesses are framing their operations to become more efficient in terms of time and money to meet the expectations of consumers. The implementation of these policies becomes complicated in food industry considering the perishable nature of food products (Aung and Chang, 2014). The food products reaching the consumers should have the virtue of good taste, quality, ample shelf life, high nutrition, appearance, good flavour in minimum cost or else the food retailers and their suppliers might lose their market share (Banović et al., 2009; Bett, 1993; Killinger et al., 2004b; Neely et al., 1998; Oliver, 2012; O'Quinn et al., 2016; Sitz et al., 2005; van Wezemael et al., 2010; van Wezemael et al., 2014; Verbeke et al., 2010). After the horsemeat scandal, major retailers are in pressure to assure the food safety, quality and precise labelling to reflect the actual content of beef products by strengthening the relation with their key suppliers (Yamoah and Yawson, 2014). There is a lot of pressure from government legislation and consumers about the carbon footprint generated in producing the food products (Weber and Matthews, 2008). The 
aforementioned factors influence the consumer's purchasing decisions. In the past, studies have been conducted to examine the impact of these factors individually (Lewis et al., 2016; Morales et al., 2013; Clark et al., 2017) or in a group of two to three factors (Hocquette et al., 2014) on consumer's buying preferences. However, literature lacks the documentary evidence on how these factors collectively impact consumer's purchasing behaviour and their interrelationship among each other. The food industries are aware of these factors. However, they do not have the insights of the linkage among the factors and the knowhow to assimilate these factors in their operations to achieve a consumer centric supply chain. Incorporating consumer's perception is very crucial for food retailers to survive in today's competitive market. Food retailers make an attempt to receive consumer feedback via market surveys, market research, interview of consumers and providing the opportunity to consumers to leave feedback in retail store and use this information for improving their supply chain strategy. However, the response rates for these techniques are quite low, often the responses are biased and consists of false information; consumers are reluctant to participate due to privacy issues. Therefore, these techniques give limited outlook of the expectation of majority of customers. There are plenty of useful information available on social media. Such information includes the true opinion of consumers (Katal et al., 2013; Liang and Dai, 2013). The rapid development in information and technology will assist business firms to collect the online information to use it in developing their future strategy. On the contrary, the social media data is qualitative and unstructured in nature and often huge in terms of velocity, volume and variety (Mishra \& Singh, 2016; Hashem et al., 2015; He et al., 2013; Zikopoulos and Eaton, 2011).

Outcome of operation management tools and techniques are usually based on limited data collected from various sources such as surveys, interviews, expert opinions, etc. Decision making could be more precise and accurate if these analyses are supplemented by social media data. This study attempts to incorporate social media data using Interpretive Structural Modelling (ISM) and fuzzy MICMAC to develop a framework for consumer centric sustainable supply chain. The involvement of information from social media data will give consumers 'sense of empowerment.' There is no mechanism mentioned in the literature for using Twitter analytics to explore the interrelationships among factors mandatory to achieve consumer centric supply chain. This article explicitly investigates the interaction among these factors using big data (social media data) supplemented with ISM and fuzzy MICMAC analysis. A systematic literature review was conducted to identify the drivers influencing the consumer's decision of buying beef products and supply chain performance. Thereafter, ISM is developed to investigate factors influencing the beef purchasing decision of consumers and the relationships between them. Usually, structural models are composed of graphs and interaction matrices, signal flow graphs, delta charts, etc., which do not provide enough explanation of the representation system lying within. In this article, using ISM and fuzzy MICMAC techniques, the variables influencing consumers' decision are segregated into four different categories: driving, linkage, autonomous and dependent variables and generate the hierarchical structure to represent the linkage between the variables for interpretive logic of system engineering tools. Based on the findings, the recommendations have been prescribed to develop a consumer centric sustainable supply chain.

The organisation of the article is as follows: Section 2 consists of literature review. In Section 3 , cluster analysis and ISM methodology are described in detail. Section 4 introduces and 
analyses ISM fuzzy MICMAC Analysis. Section 5 includes discussion, managerial implications and theoretical contribution. Finally, Section 6 provides conclusion and recommendations for future research.

\section{Literature review}

Food supply chain consists of all the operations that explain how food is transferred from farm to fork. It includes various processes like production, processing, distribution, marketing, retailing, consumption and disposal. The beef supply chain is composed of various segments viz. farmers, abattoir, processor, logistics and retailer. The beef farmers raise the cattle in beef farms from the age of three to thirty months based on the breed and demand of the cattle within the market. The cattle are transferred to abattoir and processor when they reach their finishing age. Then, they are butchered and cut into primals, which is followed by processing them into beef products like joint, steak, mince, burger, veal, dicer/stir-fry etc. The packaging and labelling of these fine beef products are performed and then they are transferred to retailer by employing logistics. In order to flourish in the competitive environment, food retailers have to provide excellent quality products at minimal cost, at precise time in right condition by incorporating virtues like food safety, eco-friendly products, good flavour, high nutrition etc.

Using systematic literature review, different variables influencing customer's buying behaviour of beef products are identified. The research papers were extracted from prominent databases like ScienceDirect, Springer, Emerald, Taylor and Francis and Google Scholar. The articles considered in this study were published in the duration of 2000-2016. The keywords utilised for searching the aforementioned databases are shown in Table 1. Initially, 3295 articles are obtained using these keywords, which included leading journal articles, international conference proceedings and reputed government reports predominantly in the domain of food quality, meat safety, marketing, meat sciences, environmental sciences and animal sciences. A preliminary screening was performed on these articles by assessing the title and abstract of article to filter the articles based on relevance to this study. The articles in non-English language and duplicates were also eliminated. The preliminary screening generated 374 articles. A deeper analysis of these articles was performed to limit the system boundary of the articles to retail beef cuts only, which are sold to customers in retail stores. The full text analysis of these studies revealed that some of them were not directly related to our domain of study as they were based on processed beef products and meals cooked from beef. Also, some of the articles were repetitive in nature considering the similarity in their findings. The elimination of the aforementioned studies via full text analysis yielded 87 most relevant articles to our research.

$<<$ Include Table 1>>

The exhaustive analysis of these studies along with interviews of consumers of beef products, supermarket technologists monitoring the performance of beef products and prominent academics working in the domain of beef supply chain generated eleven drivers as shown in Table 2, which influence the consumer's decision to purchase beef products and are essential to achieve consumer centric supply chain. The extracted drivers are described as follows: 
2.1 Quality of the meat - International Organization for Standardization (ISO) has defined food quality as the entirety of traits and characteristic of a food product that has the capability to appease fixed and implicit requirements (ISO 8402). The eating quality is the foremost thing taken into account by customers while purchasing beef, which includes tenderness, juiciness, freshness, minimum gristle and free from bad smell or rancidity and absence of infections (Banovic et al., 2009; Brunsø et al., 2005; Krystallis et al., 2007; Koohmaraie and Geesink, 2006). Good quality beef products boost the customer satisfaction and consequently raise the rate of consumption of beef products. It will lead to the increase in revenue of beef industry, which is crucial in modern era of economic crisis, uncertainty in food prices and intensive competition (Acebron \& Dopico, 2000; Verbeke et al., 2010). The determinants of quality as mentioned above are normally assessed after cooking of beef products (Grunert, 1997). Some consumers also consider credence characteristics of beef products while evaluating their quality (Geunert et al., 2004). Sometimes, the quality is also judged by the labels associated with reputed farm assurance schemes such as Red Tractor. It confirms that appropriate animal welfare procedures or farm assurance schemes have been implemented in the beef farms associated with beef products in the retail stores. Therefore, the quality of beef products plays a vital role in deciding whether a particular beef product consumed by a consumer will be bought again or recommended by him or her to their friends and relatives.

2.2 Taste - Certain consumers give equal preference to the flavour profile of beef products rather than to the aggregate sensory experience (Neety et al., 1998). Flavour of beef products often becomes the most crucial determinant for eating satisfaction if the associated tenderness is within tolerable range (Killinger et al., 2004a). The flavour associated with beef products is not easy to anticipate and define (McIlveen and Buchanan, 2001). The determinants of beef flavour have been recognised as cooked beef fat, beefy, meaty/brothy, serum/bloody, grainy/cowy, browned and organ/liver meat (Bett, 1993). Many of these determinants are unfavourable for customers. O'Quinn et al. (2016) revealed that customers prefer the beef with high cooked beef fat, meaty/brothy, beefy and sweet flavour whereas organ/livery, gamey and sour flavour were disliked. In most of the cases, customers assess the aggregate intensity of the flavour. Although the studies based on consumer's sensory have revealed that beef customers have distinct priorities for a certain attribute of beef flavour (Oliver, 2012; Killinger et al, 2004b). These individual flavour priorities are emulated in their decisions regarding purchase of beef products (Sitz et al., 2005).

2.3 Packaging - Packaging is one of the crucial visual determinants affecting the customer's decision to purchase beef (Issanchou, 1996). Packaging plays a vital role in increasing the shelf life of beef products and impedes the deterioration of food quality and insures the safety of meat (Zakrys et al., 2009). Brody and Marsh (1997) and Kerry et al. (2006) have further defined the role of packaging as to prevent from microbial infection, hamper spoilage and provide opportunity for activity by enzymes to boost tenderness, curtail loss of weight and if relevant to maintain the cherry red colour in beef products at retail shelves. Various packaging methods are followed by 
supermarkets, all of them have distinct characteristics and modes of application. Some of the major packaging systems followed are: overwrap packaging designed for chilled storage for shorter duration, Modified Atmosphere Packaging (MAP) intended for storing at chilled temperature or display at retail shelves for longer duration and Vacuum Skin Packaging (VSP), which is capable for storage at chilled temperature for a very long time (Kerry et al., 2006). As the packaging used has a great influence on colour of beef products, the packaging method used also have a great impact on consumer's approach towards beef products (Grobbel et al., 2008). A close association has been documented among the preference of colour and making a decision to purchase beef product (Carpenter, Cornforth and Whittier, 2001). Packaging of beef products also plays a crucial role in terms of marketing such as a mode of differentiation among products, value adding and a bearer of brands, labels, origin, etc. (Bernués, Olaisola and Corcoran, 2003). Visual cues like packaging and packaging associated traits considerably affect the decision of customers for purchasing beef products (Grobbel et al., 2008; Verbeke et al., 2005).

2.4 Colour - It is considered as one of the important determinants of quality of beef products (Issanchou, 1996). Colour of the meat gives an intrinsic cue to the customers regarding the freshness of beef products (McIlveen and Buchanan, 2001). Customers attempt to judge the tenderness, taste, juiciness, nutrition, and freshness from the colour of the beef products prior to purchase (Grunert, 1997; Font-i-Furnols and Luis Guerrero, 2014). Most of the customers prefer the fresh red cherry like colour in their beef products (Brody and Marsh, 1997; Kerry et al., 2006). Customers are very reluctant to buy beef products if the fresh red colour is missing despite the fact its shelf life has not expired. Modified Atmosphere Packaging (MAP) is very popular among them where they could see the colour of beef products to make a decision to buy or not to buy beef products. The discoloration of meat hampers the shelf life post preparation at retail, which is an important financial concern in beef industry (Jeyamkondan and Holley, 2000). Dark cutting beef products have always been rejected by customers and have caused significant loss to the beef industry (Viljoen et al., 2002). Usually, the colour of beef products has significant impact on consumer's perception.

2.5 Carbon footprint - Beef products contain one of the highest carbon footprints among the agro products (Singh et al., 2015). Therefore, sustainable consumption is considered to be of vital significance (Nash, 2009). The cost of food product rises in order to reduce their carbon footprint. Price is considered as the major obstacle for the purchase of sustainable product by consumers (Grunert, 2011; Röös and Tjärnemo, 2011). Sustainable consumption can be encouraged by involvement of consumers, recognizing the impact of sustainable products and by increasing the peer pressure in society (Veremeir and Verbeke, 2006). Consumers are increasingly demonstrating their awareness towards sustainable consumption by doing eco-friendly shopping especially food products including beef (Grebitus et al., 2013; Onozaka et al., 2010). It was observed that if low carbon footprint alternative exists for products with high carbon footprint at similar or lesser prices then consumers would be prioritising the low carbon footprint option (Lanz et al., 2014; Vlaeminck et al., 2014). The carbon 
footprint associated with beef product will be an important driver for the consumers to purchase beef products.

2.6 Organic/Inorganic - Consumers buy organic food because of various reasons like nutrition value, eco-friendly nature of organic products, welfare of animals, safety of food products etc. (Hughner et al., 2007). The organic beef is assumed to be derived from livestock raised by free-range procedures (Mesías et al., 2010). It was found that consumers were happy to pay extra for organic beef if sufficient information about organic farming is provided (Napolitano et al., 2010). The literature suggests distinct behaviour of consumers towards organic food products bases on social demographics (Padilla et al., 2013; Squires et al., 2001). Consumers are persuaded by social identification while purchasing organic food products (Bartels and Reinders, 2010).

2.7 Price - Price plays a crucial role in assessment of products by consumers (Marian et al., 2014). Price could be perceived as an amount of money spent by consumers for a particular transaction (Linchtenstein and Netemeyer, 1993). It is usually considered as a determinant of quality i.e. high price products are often associated with better quality (Erickson and Johansson, 1985; Völckner and Hofmann, 2007). Price could also be a barrier for low income consumers to buy high quality or organic food products (Marian et al., 2014). Price of beef product is affected by the packaging system used as well. Kukowski, Maddock and Wulf (2004) observed that consumers gave similar ratings to beef products in terms of prices based on their overall liking of the beef products. Price is a crucial factor affecting the customer's decision to purchase beef products.

2.8 Traceability - Traceability labels are considered to be the most potent means for developing trust among consumers regarding quality and food safety (Becker, 2000). Consumers are laying more emphasis on food traceability because of the rising concern associated with food safety (Zhang and Wahl, 2012). Especially after horsemeat scandal, customers are more conscious of traceability of food products. Consumers gave equal importance to traceability as quality certificate (Ubilava and Foster, 2009). It was revealed that people were ready to pay considerable amount of premium for traceable beef products as compared to conventional beef products (Lee et al., 2011). Apart from assisting customers in speculating the quality of beef products, tractability labels affect the complete attitude of consumers towards purchasing of food products, preparation of dishes, contentment and forthcoming buying decision (Bruns $\varnothing$ et al., 2002; Grunert, 2005).

2.9 Nutrition - Consumers have mixed perceptions about the nutrition value of beef products (Van Wezemael et al., 2010). Some customers have concerns about the amount of fat in beef products and its consequences on their cholesterol levels (Van Wezemael et al., 2014). However, the beef is a very rich source of good quality protein, minerals like zinc and iron, Vitamin-D, B12, B3, Selenium and essential Omega-3 fatty acid, all of which are essential components for healthy human body (McAfee et al., 2010; De Smet and Vossen, 2016; Egan et al., 2001; Pethick et al., 2011). Nutrition labelling has a good influence over consumer decision of buying 
food products (da Foneseca and Salay, 2008; Nagya, 2008; Rimal, 2005). Some consumers who are conscious about their health also refer to the nutritional labelling. Food and health are interrelated to each other and they have a direct impact on body functions and disease risk reduction. Both nutrition and health claims are based on nutrition labelling and usually consumers process this information during decision making process (Lähteenmäki, 2012; Lawson, 2012). During the study, it was found that health claims outperform nutrition claims (Barreiro-Hurlé et al., 2009).

2.10. Promotion - Promotion is a valuable tool for marketing to make an impact on consumer's purchase behaviour (Kotler and Armstrong, 2006). Food promotion could be defined as sales and marketing promotions utilised on food packaging for the purpose of alluring consumers to buy food products at the retailer's point of sale (Hawkes, 2004). It may comprise of prime deals like discounts, contests and advocacy by celebrities (Hawkes, 2004). Basically, marketing promotion has a precise function of developing awareness of a brand, benign perception towards a brand and encourage desire to purchase (Belch and Belch, 1998; Rossiter and Percy, 1998). As beef products are usually expensive in nature, promotions and deals play a crucial role in prompting consumers to purchase beef products in larger quantities.

2.11. Advertisement - Advertising is an effective tool for retailers to promote their products and develop into persuasive brand (De Chernatony and McDonald, 2003). There are some barriers in promoting beef products via advertising. They are increased expenses, unreliability of advertisements and intangibility of content of advertisement messages (Dickson and Sawyer, 1990; Quelch, 1983). Advertisement via different channels such as newspapers, radio, television influences consumer's buying behaviour. Sometimes, retailers attempt to launch their new products at farm festivals, food shows etc. (Mason and Nassivera, 2013). Retailers launch their new products like organic beef products, high nutrition low fat products via these channels. During the study, it was found that festivals help food industries to raise awareness about quality and satisfaction of food products and consequently help them to gain broader market share.

To investigate the association among the above identified variables, consumer's perception from social media data along with experts' opinions have been combined and analysed using ISM and fuzzy MICMAC, which is explained in detail in following section.

\section{Methodology}

Initially, consumers' opinion is extracted from social media (Twitter), which is rich in nature and provides unbiased opinion unlike consumer interviews, surveys, etc. Social media data is true representation of consumers' attitude, sentiments, opinions and thoughts. Cluster analysis is performed on the data collected from Twitter to find out the relation among above identified eleven variables. Thereafter, ISM and fuzzy MICMAC have been implemented to develop a theoretical framework. In the next subsection, firstly, the social media and cluster analysis are explained. Thereafter, ISM and fuzzy MICMAC are implemented to develop frameworks with the factors interlinked to each other at the various levels. 


\subsection{Social media data and cluster analysis}

In order to capture, real time observation of consumers' reactions, attitudes, thoughts, opinions and sentiments towards the purchase of beef products, social media data from Twitter has been utilised. Using NCapture tool of NVivo 10 software, tweets were extracted using keywords shown in Table 3. In total, 1,338,638 tweets were extracted from Twitter. These tweets were filtered so that only English tweets will be captured. Then, they were further refined so that tweets corresponding to only our domain of study i.e. 'factors influencing purchasing behaviour or disappointment of beef products of consumers' are selected. After refining, 26,269 tweets were left for analysis, which are associated with the domain of this study. These tweets were then carefully investigated by the experts in the area of marketing management, supply chain management, meat science and couple of them as the Big Data professionals. Content analysis has been performed. In the initial stage, conceptual analysis is employed to determine the frequency corresponding to each factor. Thereafter, the collected tweets have been classified into eleven clusters as mentioned above. The association among these clusters is examined using total linkage clustering method. Pearson correlation coefficient is used to evaluate the relationship between variables. The distance between the clusters is calculated based on frequency and likeness of occurrence. The results of the analysis are depicted in Table 4 . The pairs of variables having score 0.9 or above are considered to be interrelated. The remaining pairs of variables or clusters are not related to each other. The results of Pearson correlation coefficient test suggested that consumers are looking for good quality beef products at reasonable price while purchasing meat. They put great emphasis on taste and nutritional value associated with it as they are the significant drivers for the purchase of beef products. The traceability of beef products is also sought by consumers because of the food safety concern along with the carbon footprint generating in producing them considering the rising environmental concern. Finally, the packaging of the beef products and the organic/inorganic label have a significant influence on consumers' preferences while purchasing beef products.

The outcome of cluster analysis is transferred to ISM to identify the driver, dependent, independent and linkage variable and interrelationships between them. The detailed description of ISM is illustrated in the following subsections.

$$
\begin{aligned}
& \text { < Include Table 3>> } \\
& <<\text { Include Table 4>> }
\end{aligned}
$$

\subsection{Interpretive Structural Modelling (ISM) methodology}

ISM is a methodology for identifying and summarising relationships among specific items, which define an issue or a problem (Mandal and Deshmukh, 1994). The method is interpretive in a sense that group's judgement decides whether and how the variables are related. It is primarily intended as a group learning process. It is structural in a sense that an overall structure is extracted from the complex set of variables based on their relationships. It is a modelling technique to depict the specific relationships and overall structure in the digraph model (Agarwal et al., 2007). The ISM methodology helps to enforce order and 
direction on the complexity of the relationships among the variables of a system (Haleem et al. 2012; Purohit et al., 2016; Sage, 1977). For problems, such as understanding the factors considered by the customers while purchasing beef, several of them may be impacting each other at different levels. However, the direct and indirect relationships between the factors describe the situation far more precisely than the individual factors considered in isolation. ISM develops insights into the collective understanding of these relationships. ISM methodology has been successfully implemented in various domains. Hughes et al., (2016) have employed ISM to identify the root causes of failure of information systems project and interrelationship between them. Gopal and Thakkar, (2016) have used ISM and MICMAC analysis to investigate the critical success factors (and their contextual relationships) responsible for sustainable practices in supply chains of Indian automobile industry. Kumar et al., (2016) have utilised ISM to identify barriers for implementation of green lean six sigma product development process. Haleem et al., (2012) have applied ISM techniques to develop a hierarchical framework for examining the relationship among critical success factors behind the successful implementation of world leading practices in manufacturing industries. Mathiyazhagan et al., (2013) have used ISM to identify the barriers in implementing green supply chain management in Indian SMEs manufacturing auto components. Mani et al., (2015a) have employed ISM to explore different enablers and the interactions among them in incorporating social sustainability practices in their supply chain. Mani et al., (2015b) have developed ISM model to investigate the barriers (and their contextual relationships) to adoption of social sustainability measures in Indian manufacturing industries. Dubey and Ali, (2014) have applied ISM, fuzzy MICMAC and Total Interpretive Structural Modelling (TISM) to explore the major factors responsible for flexible manufacturing systems. Sindhu et al., (2016) have used ISM and fuzzy MICMAC to identify and analyse the barriers to solar power installation in rural sector in India. Singh et al., (2007) used ISM for improving competitiveness of small and medium enterprises (SMEs). Agarwal et al., (2007) used ISM to understand the interrelationships of the variables influencing the supply chain management. Similarly, Pfohl et al., (2011) used ISM to perform the structural analysis of potential supply chain risks. Talib et al., (2011) used the ISM to analyse the interaction among the barriers to total quality management implementation. The application of ISM typically forces managers to reassess perceived priorities and improves their understanding of the linkages among key concerns (Singh et al., 2007).

ISM starts with identifying variables, which are pertinent to the problem and then extends with a group problem-solving technique. A contextually significant subordinate relation is chosen. Having decided on the element set and the contextual relation, a structural selfinteraction matrix (SSIM) is developed based on pair-wise comparison of variables. In the next step, the SSIM is converted into a reachability matrix and its transitivity is checked. Once transitivity embedding is complete, a matrix model is obtained. Then, the partitioning of the elements, development of the canonical form of the reachability matrix, driving power and dependence diagram and an extraction of the structural model, called ISM is derived (Agarwal et al., 2007). The execution process of ISM is shown in Figure 1. 
In this research, ISM has been applied to develop a framework for the factors considered by the consumers while purchasing beef to achieve the following broad objectives: (a) to derive interrelationships among the variables that affect each other while consumers make decisions to purchase beef, and (b) to classify the variables according to their driving and dependence power using a $2 \times 2$ matrix, which represents the relationships between different factors that decide the consumers' intention to purchase beef.

\subsubsection{Interpretive logic matrix}

Although, the Pearson correlation coefficient test has revealed the association between factors, it is not clear what kind of association or relationship they have among themselves. In order to identify the relationship, the experts' opinion has been collected. Experts having considerable experience and operating at crucial stages in food supply chain were approached. The results obtained from Big Data analysis have been circulated to the experts and session was organised to establish the relationships between each pair of variable. The brainstorming session was conducted for several hours and then final consensus was reached on the SSIM matrix as shown in Table 5. To express the relationships between different factors (i.e. Price, quality, packaging, taste, organic/inorganic, promotion, advertisement, carbon footprint, traceability, colour and nutrition) that decide the consumers' intention to purchase beef, four symbols were used to denote the direction of relationship between the parameters $i$ and $j($ here $i<j)$ :

$\mathrm{V}-$ Construct $\mathrm{i}$ helps achieve or influences $\mathrm{j}$,

A - Construct $\mathrm{j}$ helps achieve or influences $\mathrm{i}$,

$\mathrm{X}-$ Constructs $\mathrm{i}$ and $\mathrm{j}$ help achieve or influence each other, and

$\mathrm{O}-$ Constructs $\mathrm{i}$ and $\mathrm{j}$ are unrelated

The following statements explain the use of symbols V, A, X, O in SSIM:

[1] Quality (Variable 1) helps achieve or influences quality (Variable 4) (V)

[2] Packaging (Variable 3) helps achieve or influences quality (Variable 1) (A)

[3] Promotion (Variable 5) and advertisement (Variable 7) help achieve or influence each other $(\mathrm{X})$

[4] Advertisement (Variable 7) and traceability (Variable 10) are unrelated (O)

Based on contextual relationships, the SSIM is developed as shown in Table 5.

$<<$ Include Table 5>>

\subsubsection{Reachability matrix}

The SSIM has been converted into a binary matrix, called the initial reachability matrix, by substituting V, A, X, and $\mathrm{O}$ with 1 and 0 as per the case. The substitution of $1 \mathrm{~s}$ and $0 \mathrm{~s}$ are as per the following rules: 
[1] If the (i, j) entry in the SSIM is $V$, the $(i, j)$ entry in the reachability matrix becomes 1 and the $(\mathrm{j}, \mathrm{i})$ entry becomes 0 .

[2] If the (i, j) entry in the SSIM is A, the $(i, j)$ entry in the reachability matrix becomes 0 and the $(j, i)$ entry becomes 1 .

[3] If the $(i, j)$ entry in the SSIM is X, the $(i, j)$ entry in the reachability matrix becomes 1 and the $(j, i)$ entry becomes 1 .

[4] If the $(i, j)$ entry in the SSIM is $\mathrm{O}$, the $(i, j)$ entry in the reachability matrix becomes 0 and the $(j, i)$ entry becomes 0 .

Following these rules, the initial reachability matrix for the trustworthiness factors influencing the beef purchasing decision is shown in Table 6.

$<<$ Include Table 6>>

We used 'transitivity principle' to develop the final reachability matrix (Dubey and Ali, 2014; Dubey et al., 2015a, 2015b; Dubey et al., 2016). This principle can be clarified by the use of following example: if ' $a$ ' leads to ' $b$ ' and ' $b$ ' leads to ' $c$ ', the transitivity property implies that ' $a$ ' leads to ' $c$ '. This property assists to eliminate the gaps among the variables if any (Dubey et al., 2016). By following the above criteria, the final reachability matrix is created and is shown in Table 7. Table 7 also shows the driving and dependence power of each variable. The driving power for each variable is the total number of variables (including itself), which it may help to achieve. On the other hand, dependence power is the total number of variables (including itself), which may help in achieving it. As per Dubey and Ali (2014), driving power is calculated by adding up the entries for the possibilities of interactions in the rows whereas the dependence is determined by adding up such entries for the possibilities of interactions across the columns. These driving power and dependence power will be used later in the classification of variables into the four groups including autonomous, dependent, linkage and drivers (Agarwal et al., 2007; Singh et al., 2007).

$$
<<\text { Include Table 7>> }
$$

\subsubsection{Level partitions}

The matrix is partitioned by assessing the reachability and antecedent sets for each variable (Warfield, 1974). The final reachability matrix leads to the reachability and antecedent set for each factor relating to consumer's purchase of beef. The reachability set $\mathrm{R}\left(\mathrm{s}_{\mathrm{i}}\right)$ of the variable $\mathrm{s}_{\mathrm{i}}$ is the set of variables defined in the columns that contained 1 in row $\mathrm{s}_{\mathrm{i}}$. Similarly, the antecedent set $\mathrm{A}\left(\mathrm{s}_{\mathrm{i}}\right)$ of the variable si is the set of variables defined in the rows, which contain 1 in the column $s_{\mathrm{i}}$. Then, the interaction of these sets is derived for all the variables. The variables for which the reachability and intersection sets are same are the top-level variables of the ISM hierarchy. The top-level variables of the hierarchy would not help to achieve any other variable above their own level in the hierarchy. Once the top-level variables are identified, it is separated out from the rest of the variables. Then, the same process is repeated to find out the next level of variables and so on. These identified levels help in building the digraph and the final ISM model (Agarwal et al., 2007; Singh et al., 2007). In the present 
context, the variables along with their reachability set, antecedent set, and the top level is shown in Table 8. The process is completed in 3 iterations (in Tables 8-11) as follows:

In Table 8, only one variable price (Variable 4) is found at level I as the element (i.e., Element 4 for Variable 4) for this variable at reachability and intersection set are same. So, it is the only variable that will be positioned at the top of the hierarchy of the ISM model.

$$
<<\text { Include Table 8>> }
$$

In Table 9, maximum seven variables including 1 (i.e., quality), 2 (i.e., taste), 5 (i.e., promotion), 7 (i.e., advertisement), 8 (i.e., colour), 9 (i.e., nutrition) and 11 (i.e., carbon footprint) are put at level II as the elements (i.e., elements 1, 2, 6, 9 and 11 for variable 1; elements 1, 2, 9 and 11 for variable 2; elements 5 and 7 for each of the variables 5 and 7; element 8 for variable 8; elements 1,2, 9 and 11 for variable 9; and elements 1, 2, 6, 9 and 11 for variable 11) for these variables at reachability and intersection set are same. Thus, they will be positioned at level II in the ISM model. Moreover, we also remove the rows corresponding to variable 4 from Table 9, which are already positioned at the top level (i.e., Level I).

\section{$<<$ Include Table 9>>}

The same process of deleting the rows corresponding to the previous level and marking the next level position to the new table is repeated until we reach to the final variable in the table. In Table 10, variable 3 (i.e., packaging), variable 6 (i.e., organic/inorganic) and variable 10 (i.e., traceability) are kept at Level III as the elements (i.e., element 3 for variable 3; element 6 for variable 6; and element 10 for variable 10) at reachability set and intersection set for all these variables are same. Thus, it will be positioned at Level III in the ISM model.

$$
<<\text { Include Table 10>> }
$$

\subsubsection{Developing canonical matrix}

A canonical matrix is developed by clustering variables in the same level, across the rows and columns of the final reachability matrix as shown in Table 11. This matrix is just the other more convenient form of the final reachability matrix (i.e., Table 7) as far as drawing the ISM model is concerned.

$$
<<\text { Include Table 11>> }
$$

\subsubsection{Formation of ISM}

From the canonical form of the reachability matrix as shown in Table 11, the structural model is generated by means of vertices and nodes and lines of edges. If there is a relationship between the factors $i$ and $j$ considered by the consumers while purchasing beef, this is shown by an arrow that points from $i$ to $j$. This graph is called directed graph or digraph. After 
removing the indirect links as suggested by the ISM methodology, the digraph is finally converted into ISM-based model as depicted in Figure 2.

$$
<<\text { Include Figure 2>> }
$$

In the ISM methodology, binary digits ( 0 and 1$)$ are considered. If there is a linkage then relationship is denoted by 1 and if there is no linkage then, 0 is used to denote the relationship. The strength of relationship between two factors is not being taken into account in this methodology. The relationship among two factors could be no relationship, very weak, weak, strong and very strong. The shortcoming of this methodology is addressed by using ISM fuzzy MICMAC analysis, which is described in the next section.

\section{ISM fuzzy MICMAC analysis}

In the ISM model, we have considered binary digits i.e. 0 or 1 . If there is no linkage between the variables, then the relationship is denoted by 0 and if there is linkage then the relationship is denoted by 1 . However, there is no scope for discussion in this matrix about the strength of relationship. The relationship between any two variables in the matrix could be defined as very weak, weak, strong and very strong or there is no relationship between them at all. To overcome the limitations of ISM modelling, a fuzzy ISM is used for MICMAC analysis (Gorane and Kant, 2013). The steps for ISM fuzzy MICMAC analysis are performed as follows:

\subsection{Synthesis of Direct Relationship Matrix (DRM)}

Making diagonal entries zero and ignoring transitivity in the final reachability matrix generate DRM (see Table 12). In the current context, it is essentially the calculation of direct relationships among the variables influencing consumers' beef purchasing behaviour.

$$
\text { <<Include Table 12〉> }
$$

\subsection{Developing Fuzzy Direct Relationship Matrix (FDRM)}

A fuzzy direct relationship matrix (FDRM) was constructed by putting a diagonal series of zero values into the correlation matrix (Table 13), and, by ignoring the transitivity rule of the initial RM. The traditional MICMAC analysis considers only a binary interaction and therefore to improve the sensitivity of traditional MICMAC analysis, fuzzy set theory has been used. The investigation is more enhanced as it considers the "possibility of reachability/achievement" in addition to the simple deliberation of reachability used thus far. According to the theory of fuzzy set, the possibilities of additional interactions between the variables on the scale 0-1 (Qureshi et al., 2008) are constructed using the specifications: No 0, Negligible - 0.1, Low - 0.3, Medium - 0.5, High - 0.7, Very High - 0.9 and Full -1. By using these values, again the judgments of same experts are considered to rate the relationship between two key variables influencing consumers' beef purchasing behavior. Fuzzy direct relationship matrix (FDRM) for key variables influencing consumers' beef 
purchasing behavior is presented in Table 13 .

$<<$ Include Table 13>>

\subsection{Developing fuzzy stabilised matrix}

The concept of fuzzy multiplication is used on FDRM to obtain stabilization (Saxena and Vrat, 1992). This notion states that matrix is multiplied until the values of driving and dependence powers are stabilized (Qureshi et al., 2008). Driving and dependence power are obtained by adding row and column entries separately. The stabilized matrix for fuzzy MICMAC for variables influencing consumers' beef purchasing behaviour is obtained in Table 14.

$<<$ Include Table 14>>

\subsection{Classification of categories of variables using MICMAC analysis}

The classification of variables has been divided into four categories based on dependence and driving powers by using fuzzy MICMAC analysis. Figure 3 shows that there are four categories in which these 11 variables are assigned as per their new driving and dependence power. The first region belongs to autonomous variables, which have less driving and less dependence power. These variables lie nearby origin and remains disconnected to entire system. Three variables 5 (i.e. promotion), 7 (i.e. advertisement) and 8 (i.e. colour) falls under this cluster. The second region belongs to dependence variables, which have high dependence and low driving power. The only variable falls under this cluster is 4 (i.e. price), which indicates price as the ultimate dependent variable as it can be visualized from the previous MICMAC analysis as well. The third region belongs to linkage variables, which have high driving and high dependence power. In the modified MICMAC analysis, highest five variables including 1 (i.e. quality), 2 (i.e. taste), 6 (i.e. organic/inorganic), 9 (i.e. nutrition) and 11 (i.e. carbon footprint) fall in this category. The fourth and final category of variables belongs to independent variables, which have high driving and low dependence power. Two variables 3 (i.e. packaging) and 10 (i.e. traceability) fall under this region. These are the key driving variables and are generally found at the bottom of the ISM model.

$<<$ Include Figure 3>>

\subsection{Integrated ISM model development}

An integrated ISM model is developed using the driving and dependence powers obtained from fuzzy stabilized matrix. The value of dependence power is subtracted from driving power to obtain the effectiveness of each variable, which is shown in Table 15 . The variables having low value of effectiveness are placed at the bottom levels in the model. The integrated model of variables influencing consumers' beef purchasing behaviour is drawn from the values of effectiveness as shown in Figure 4. 
$<<$ Include Table 15>>

$<<$ Include Figure 4>>

\subsection{Comparison of ISM and ISM-Fuzzy MICMAC based models}

This research first identified factors influencing consumer's beef purchasing decisions using literature survey and social media Big Data analysis and implemented ISM based model to understand the interrelationships between these factors across different levels. In the ISM model, we have considered binary digits i.e. 0 and 1 , however this methodology does not provide any further details about the strength of relationship. The relationship between two factors could be very weak, weak, strong or very strong or there is no relationship. To overcome the limitations of ISM model, the Fuzzy ISM is used for the MICMAC analysis (Dubey and Ali, 2014). The ISM model splits the factors only into three levels whereas integrated ISM expands it into eight levels. The ISM model shown in Figure 2 shows the contribution of factors such as packaging (3), organic/inorganic (6) and traceability (10) at Level 3 and form the foundation of the ISM hierarchical structure for the factors influencing consumer's beef purchasing decisions. However, in the integrated ISM model only traceability (10) is shown to be at the very bottom level indicating it as a key driving factor to identify other factors influencing consumer's beef purchasing decisions whereas the other two factors i.e. packaging (3) and organic/inorganic (6) were found at Level 7 and Level 3 respectively. This clearly indicates that factors 3 (i.e. packaging) and 10 (i.e. traceability) have higher effectiveness in terms of drivers in the integrated ISM as well. However, organic/inorganic factor has been found more toward the upper level (i.e. Level 3) in the integrated ISM model. There are six variables in the ISM model at Level 2, which have got scattered over five different levels in between the top and the bottom levels (i.e. from Level 2 to Level 6) in the integrated ISM model. In other words, the integrated ISM model (see Figure 4) provides more detailed levelling of each one of the factors shown in Level 2 in the ISM model (see Figure 2). However, from the integrated ISM model, it can be understood that a factor placed at a definite level will not aid in accomplishing any other factor placed at the level above it. For example, the factors placed at Level 5 such as promotion (5) and colour (8) would not facilitate in accomplishing any other factors such as taste (2), quality (1), carbon footprint (11) and nutrition (9) which are placed above them and were not distinguished at different levels in the ISM model. As far as the key dependent variable (i.e. price (4)) is concerned, it remains same for both ISM and integrated ISM models. This indicates that all middle level variables, no matter what levels they are placed at, can influence price, which has the highest influence on the consumer's willingness to purchase beef products. 


\section{Discussion}

During the investigation, it was found that consumers' buying preferences while purchasing beef products are vastly dependent on their price. The variable 'price' has high dependence and low driving power. It is dependent on nutritional value and ongoing promotions. The beef derived from grass-fed cattle is higher in nutrition in terms of omega-3 fatty acid, conjugated linoleic acid (CLA) and have lower amounts of saturated and monounsaturated fats as compared to grain-fed cattle (Daley et al., 2010). The grass-fed cattle takes more time to reach finishing age (Profita, 2012) and are more expensive than grain-fed cattle (Gwin, 2009). The ongoing promotions in retail stores have a direct influence on the price of the beef products (Darke and Chung, 2005).

The variables like quality, taste, carbon footprint, organic/inorganic and nutrition have high dependence and high driving power in terms of influencing consumer's decision for purchasing beef products. Quality and organic/inorganic are interrelated variables as depicted in Figure 4. The organic/inorganic label in beef products reflects the sustainable practices used in the production of beef products and are associated with high quality, lower carbon footprint, higher nutrition, better taste and colour stability for longer duration of time (Fernandez and Woodward, 1999; Kahl et al., 2014; Nielsen and Thamsborg, 2005; Załęcka et al., 2014; Zanoli et al., 2013). Organic food is usually sold at a higher price than their conventionally produced counterparts. However, still, some consumers are ready to pay extra because they are worried about the food safety, impact on environment and use of pesticides, hormones and other veterinary drugs in beef farms. Organic food assists in solving the problems of animal welfare, rural development and numerous issue of food production (Capuano et al., 2013). Organic/inorganic and carbon footprint also have an interrelationship. The organic beef products associated with higher nutrition are derived from grass-fed cattle, which took more time to reach finishing age (Ruviaro et al., 2015). Hence, the beef products derived from grass-fed cattle have higher carbon footprint. Similarly, the beef products having higher carbon emission are associated with beef products derived from grass-fed cattle (organic beef) as majority of the carbon emission is generated in terms of cattle taking longer time to reach finishing age (Capper, 2012). Nutrition of beef products is found to be dependent on taste, organic/inorganic and carbon footprint as depicted in Figure 4. Excellent flavour and organic beef are considered to be a determinant of the nutritional value of beef products (Yiridoe et al., 2005). Beef products having high carbon footprint (grass-fed) have better nutritional value (Profita, 2012).

The variables promotion, advertisement and colour have low driving and dependence power. Advertisement via television, radio, social media etc. has a direct impact on promotions in retail stores. Colour of beef products is significantly influenced by the variant of packaging used. For instance, beef products in Modified Atmosphere Packaging (MAP) have shelf life of around eight to ten days where as Vacuum Skin Packaging (VSP) provides shelf life of up to 21 days (Meat Promotion Wales, 2012).

Traceability and packaging have the highest driving power and have very low dependence. The beef products produced with strict traceability procedures are often attributed with better taste, nutrition, and quality (Giraud and Amblard, 2003; Verbeke and Ward, 2006; van Rijswijk et al., 2008a; van Rijswijk and Frewer, 2008). During the study, it was found that 
traceability helps consumers to find different information related to animal breed, slaughtering, food safety and quality. Generally, retailers use traceability information to boost consumer confidence (van Rijswijk and Frewer, 2008). The variant of packaging employed in beef products affects the carbon footprint. Vacuum Skin Packaging (VSP) are lightweight, requires fewer corrugate for logistics, gives longer shelf life and thereby reduces retailer food loss and consumer food waste and requires less fuel in transport as compared to Modified Atmosphere packaging (MAP) (Mashov, 2009).

The bottom level variables viz. traceability and packaging have high driving power but no dependence on them. They strongly affect the middle level variables like promotion, advertisement, colour, quality, taste, carbon footprint, organic/inorganic and nutrition. The middle level variables in turn affect the price, which has the highest influence on the consumer's willingness to purchase beef products. Therefore, it can be concluded that two variables traceability and packaging influence the price of the beef products, which in turn has an impact on consumer's decision for purchasing beef products.

This study reveals two factors: traceability and packaging, which needs to be improved and maintained throughout the supply chain of beef retailers in order to allure consumers. For instance, many retailers utilise superior quality packaging for the beef products, however, it gets damaged within the supply chain, which could be due to mishandling at logistics, warehouse or in the retailer's store. Hence, a strong vertical coordination should be developed within the whole beef supply chain so that the quality of packaging is retained till the beef products are sold to consumers. The strong vertical coordination among all stakeholders of beef supply chain viz. farmer, abattoir, processor, logistics and retailer would also assist in achieving the traceability of beef products, which is another crucial driving factor influencing consumer's buying preferences.

Nowadays, consumers are very conscious about their health and nutrition (Van Wezemael et al., 2014; Cavaliere et al., 2015; Van Doorn and Verhoef, 2015). They are looking for food products having high nutrition and safe to consume (Liu et al., 2013; Van Wezemael et al., 2014). During the ISM fuzzy MICMAC analysis, it was found that customers makes a tradeoff between price and quality, taste, food safety, nutrition, colour while purchasing the beef products. Using proper packaging, labelling information, retailers can boost customer confidence. Further, the beef industry could utilise modern technology like cloud computing technology to bring all the stakeholders on one platform (Singh et al., 2015) and can manage the information flow effectively which will result in high quality beef products at lower carbon footprint in minimum cost and can get maximum market share.

In modern era, food industries struggle to anticipate the quantity and quality of food products to meet the expectations of consumers, which lead to overproduction of food products and reducing market share of food companies (Corrado et al., 2017; Silvennoinen et al., 2014; Garrone et al. 2014). This scenario is a mutual loss to both food industries and consumers. In order to fulfil this gap, major food retailers have taken lots of attempts to receive consumer feedback via market survey, market research, interview of consumers and providing the opportunity to consumers to leave feedback in retail store and use this information for improving their supply chain strategy (Mishra and Singh, 2016). Still, they cannot get the inputs from the larger audiences and sometimes the information gathered by these methods are biased and inaccurate. The current study utilises the social media data, which covers 
larger audience and consists of real time true opinion of consumers. The amalgamation of Twitter analytics and ISM has identified the most crucial factors (and their interrelationships) needed to achieve consumer centric supply chain. It will assist business firms to have an edge over their rivals and enhance their market share. The analysis of the crucial factors and their interrelationships will assist business firms in prioritising their actions, appropriate decision making in terms of where to start making modification to achieve consumer centric supply chains.

The current study provides some new insights into developing consumer centric beef supply chain. In the past, price and quality of beef products used to be the detrimental factors for consumers purchasing beef products (Acebrón \& Dopico, 2000; Kukowski et al., 2005; Bruns $\emptyset$ et al., 2005; Becker, 2000). However, during the study, it was observed that apart from quality and price, traceability has emerged as a high driving factor and it influences consumer's buying behaviour. After the horsemeat scandal in Europe in 2013, traceability of beef products has gained vital significance among the consumers (Henchion et al., 2017; Clemens \& Babcock, 2015; Menozzi et al., 2015). Apart from traceability, packaging also appeared as one of the prime driver influencing the consumer's beef purchasing behaviour (Verbeke et al., 2005; Grobbel et al., 2008). Along with visual cues, it has great impact on the shelf life of beef products (Grobbel et al., 2008). Experts working in beef industry also unequivocally rated it as a crucial factor affecting choices made by the consumers. This study will help beef industry to restructure their priorities to develop an efficient, resilient, and sustainable supply chain in longer run.

\subsection{Managerial implications and theoretical contributions}

The proposed framework is vital for both academia and industry in streamlining the supply chain and improving participation of all stakeholders. The revealing of interaction of various mandatory factors to achieve consumer centric supply chain would assist in improving vertical and horizontal collaboration within the supply chain. Consequently, an efficient strategy would be developed by taking the drivers into account for increasing market share of a business firm, having advantage over their rivals and developing a consumer centric supply chain. This mechanism will assist in appropriate partner selection within the supply chain to improve sustainability. It will assist the managers of small and medium size stakeholders in the supply chain, who lacks awareness about consumer priorities, such as farmers lack awareness of consumers seeking traceability in meat products.

The paper has a two-fold contribution to the literature on the consumer interest in beef. Firstly, although many research studies (e.g., Reicks et al., 2011; Robbins et al., 2003; Thilmany et al., 2006) in the beef industry have focused on the motivational factors affecting consumers' purchasing decisions while purchasing beef, none of them have offered an alternative approach to theory building emerging from the various quality characteristics and other factors that could be considered while purchasing beef. This research undertakes a comprehensive review of literature generating the most important eleven factors or clusters and devises a theoretical framework based on the interrelationships of those variables emerging from the consumers (social media data) and experts' opinion using ISM and fuzzy MICMAC analysis. Secondly, this research further extends the existing literature on 
consumers' decisions toward purchasing beef by offering a strategic framework, which is not only based on literature but also validated using the big data clustering technique that divides all such potential variables in the most important clusters that influence consumers' beef purchasing decisions. In current research, the number of such clusters coincides to eleven factors. Therefore, the proposed theoretical framework extrapolates eleven factors at eight different layers and their interrelationships highlighting the specific roles of these variables.

\section{Conclusion and future research}

Food is a significant commodity for enduring human life as compared to other essentials. In today's competitive market, consumers are very selective. To sustain in this competitive scenario, retailers have to investigate the purchasing behaviour of consumers and the factors influencing it. They must investigate how these factors are linked with each other and which of the factors belong to the category of driver, dependent, linkage and autonomous respectively. It will help the retailers in waste minimisation, streamlining their supply chain, improving its efficiency and making it more consumer centric.

In this study, initially, systematic literature review was conducted to identify the factors influencing the consumers' decision for buying beef products. Then, cluster analysis on consumers' information from Twitter in the form of big data was conducted. It assists in finding how the variables determining the consumers' beef products buying preferences are influenced. Then experts' opinion, ISM and fuzzy MICMAC analysis are used to classify eleven variables into: linkage, dependent, driver and independent variables and their interrelationships are explored. During the study, it was observed that price of the beef product is the most important criteria driving the purchasing decision of consumers. It is followed by nutrition, quality, organic/inorganic, carbon footprint, taste, promotion, colour and advertisement. Based on the findings, recommendations were given for making consumer centric supply chain. Future studies can be performed to develop a theoretical mechanism for sustainable consumer centric supply chain by assimilating some more aspects. Furthermore, confirmatory investigation of variables could be conducted to validate the theoretical framework developed. The proposed model could be validated by using Systems Dynamic Modelling (SDM) and Structural Equation Modelling (SEM). The factors identified to develop consumer centric beef supply chain could be quantified by employing Analytical Network Process (ANP) and Analytical Hierarchical Process (AHP). These factors could be further ranked by utilising Interpretive Ranking Process (IRP) to develop consumer centric beef supply chain.

\section{Acknowledgement}

The authors would like to thank the project 'A cross country examination of supply chain barriers on market access for small and medium firms in India and UK' (Ref no: PM130233) funded by British Academy, UK for supporting this research.

\section{References}


Acebrón, L. B., and Dopico, D. C. (2000). The importance of intrinsic and extrinsic cues to expected and experienced quality: an empirical application for beef. Food Quality and Preference, 11(3), 229-238.

Ali, M. H., Ali, M. H., Tan, K. H., Tan, K. H., Ismail, M. D., \& Ismail, M. D. (2017). A supply chain integrity framework for halal food. British Food Journal, 119(1), 20-38.

Aung, M. M., and Chang, Y. S. (2014). Temperature management for the quality assurance of a perishable food supply chain. Food Control, 40, 198-207.

Barnett, J., Begen, F., Howes, S., Regan, A., McConnon, A., Marcu, A., Rowntree, S. \& Verbeke, W. (2016). Consumers' confidence, reflections and response strategies following the horsemeat incident. Food Control, 59, 721-730.

Banović, M., Grunert, K. G., Barreira, M. M., and Fontes, M. A. (2009). Beef quality perception at the point of purchase: A study from Portugal. Food Quality and Preference, 20(4), 335-342. DOI: 10.1016/j.foodqual.2009.02.009

Barreiro-Hurlé, J., Gracia, A., and De-Magistris, T. (2009). Market implications of new regulations: impact of health and nutrition information on consumer choice. Spanish Journal of Agricultural Research, 7(2), 257-268. DOI:10.5424/sjstar/2009072-417

Bartels, J., and Reinders, M. J. (2010). Social identification, social representations, and consumer innovativeness in an organic food context: A cross-national comparison. Food Quality and Preference, 21(4), 347-352. DOI: 10.1016/j.foodqual.2009.08.016

Becker, T. (2000). Consumer perception of fresh meat quality: a framework for analysis. British Food Journal, 102(3), 158-176. DOI: http://dx.doi.org/10.1108/0007070001037170

Belch, G. E., and Belch, M. A. (1998). Advertising and promotion (International ed.). New York, NY: Irwin, McGraw-Hill.

Bernués, A., Olaizola, A., and Corcoran, K. (2003). Labelling information demanded by European consumers and relationships with purchasing motives, quality and safety of meat. Meat Science, 65(3), 1095-1106. DOI: 10.1016/S0309-1740(02)00327-3

Bett, K. L. (1993). Measuring sensory properties of meat in the laboratory. Food technology, 47(11), 121-126.

Bravo, C. P., Cordts, A., Schulze, B., and Spiller, A. (2013). Assessing determinants of organic food consumption using data from the German National Nutrition Survey II. Food Quality and Preference, 28(1), 60-70. DOI: 10.1016/j.foodqual.2012.08.010

Brody A.L. and Marsh (Eds.) (1997), The Wiley Encyclopedia of packaging (2nd ed.), Wiley, New York, pp. 699-704

Brunsø, K., Bredahl, L., Grunert, K. G., and Scholderer, J. (2005). Consumer perception of the quality of beef resulting from various fattening regimes. Livestock Production Science, 94(1), 83-93. DOI: 10.1016/j.livprodsci.2004.11.037

Bruns $\varnothing$, K., Fjord, T. A., and Grunert, K. G. (2002). Consumers' food choice and quality perception. MAPP working paper no 77. Aarhus: The Aarhus School of Business, MAPP Centre.

Cairns, G., Angus, K., and Hastings, G. (2009). The extent, nature and effects of food promotion to children: a review of the evidence to December 2008. Geneva: World Health Organization.

Capper, J. L. (2012). Is the grass always greener? Comparing the environmental impact of conventional, natural and grass-fed beef production systems. Animals, 2(2), 127-143. 
Capuano, E., Boerrigter-Eenling, R., Veer, G., and Ruth, S. M. (2013). Analytical authentication of organic products: an overview of markers. Journal of the Science of Food and Agriculture, 93(1), 12-28.

Carpenter, C. E., Cornforth, D. P., and Whittier, D. (2001). Consumer preferences for beef color and packaging did not affect eating satisfaction. Meat Science, 57(4), 359-363. DOI: 10.1016/S0309-1740(00)00111-X

Cavaliere, A., Ricci, E. C., \& Banterle, A. (2015). Nutrition and health claims: Who is interested? An empirical analysis of consumer preferences in Italy. Food Quality and Preference, 41, 44-51.

Chaves, A. V., Thompson, L. C., Iwaasa, A. D., Scott, S. L., Olson, M. E., Benchaar, C., ... and McAllister, T. A. (2006). Effect of pasture type (alfalfa vs. grass) on methane and carbon dioxide production by yearling beef heifers. Canadian Journal of Animal Science, 86(3), 409-418.

Clark, B., Stewart, G. B., Panzone, L.A., Kyriazakis, I., Frewer, L. J. (2017). Citizens, consuemrs and farm animal welfare: A meta-analysis of willingness-to-pay studies.

Clemens, R. L., and Babcock, B. A. (2015). Meat traceability: its effect on trade. Iowa Ag Review, 8(1), 4-9.

Corrado, S., Ardente, F., Sala, S., \& Saouter, E. (2017). Modelling of food loss within life cycle assessment: from current practice towards a systematisation. Journal of Cleaner Production, 140, 847-859.

Cox, A., and Chicksand, D. (2005). The Limits of Lean Management Thinking: Multiple Retailers and Food and Farming Supply Chains. European Management Journal, 23(6), 648-662.

da Fonseca, M. D. C. P., and Salay, E. (2008). Beef, chicken and pork consumption and consumer safety and nutritional concerns in the City of Campinas, Brazil. Food Control, 19(11), 1051-1058. DOI: 10.1016/j.foodcont.2007.11.003

Daley, C. A., Abbott, A., Doyle, P. S., Nader, G. A., and Larson, S. (2010). A review of fatty acid profiles and antioxidant content in grass-fed and grain-fed beef. Nutrition Journal, 9(1), 2-12.

Darke, P. R., and Chung, C. M. (2005). Effects of pricing and promotion on consumer perceptions: it depends on how you frame it. Journal of Retailing, 81(1), 35-47.

De Chernatony, L. and McDonald, M. (2003). Creating Powerful Brands, ButterworthHeinemann, Oxford.

De Smet, S., \& Vossen, E. (2016, October). Meat: The balance between nutrition and health, a review. Meat Science, 120, 145-156. http://dx.doi.org/10.1016/j.meatsci.2016.04.008.

Dickson, P. R. and Sawyer, A. G. (1990). The price knowledge and search of supermarket shoppers. The Journal of Marketing, 54 (3), $42-53$.

Dubey, R., and Ali, S. S. (2014). Identification of flexible manufacturing system dimensions and their interrelationship using total interpretive structural modelling and fuzzy MICMAC analysis. Global Journal of Flexible Systems Management, 15(2), 131-143.

Dubey, R., Gunasekaran, A., and Ali, S. S. (2015a). Exploring the relationship between leadership, operational practices, institutional pressures and environmental performance: A framework for green supply chain. International Journal of Production Economics, 160, 120-132.

Dubey, R., Gunasekaran, A., Papadopoulos, T., Childe, S. J., Shibin, K. T., and Wamba, S. F. (2016). Sustainable supply chain management: framework and further research 
DOI: http://dx.doi.org/10.1016/j.jclepro.2016.03.117

Dubey, R., Sonwaney, V., Aital, P., Venkatesh, V. G., and Ali, S. S. (2015b). Antecedents of innovation and contextual relationship. International Journal of Business Innovation and Research, 9(1), 1-14.

Egan, A. F., Ferguson, D. M., \& Thompson, J. M. (2001). Consumer sensory requirements for beef and their implications for the Australian beef industry. Australian Journal of Experimental Agriculture, 41, 855-859.

Eertmans, A., Baeyens, F., and Van Den Bergh, O. (2001). Food likes and their relative importance in human eating behavior: review and preliminary suggestions for health promotion. Health Education Research, 16(4), 443-456

Elliott, C. (Ed.). (2016). How Canadians Communicate VI: Food Promotion, Consumption, and Controversy. Athabasca University Press.

Epstein, L. H., Jankowiak, N., Nederkoorn, C., Raynor, H. A., French, S. A., and Finkelstein, E. (2012). Experimental research on the relation between food price changes and foodpurchasing patterns: a targeted review. The American Journal of Clinical Nutrition, 95(4), 789-809.

Erickson, G. M., and Johansson, J. K. (1985). The role of price in multi-attribute product evaluations. Journal of Consumer Research, 195-199.

Garrone, P., Melacini, M., \& Perego, A. (2014). Opening the black box of food waste reduction. Food policy, 46, 129-139.

Fei, L., YuanHua, L., WenJie, Z., Kun, S., HaiPeng, L., ZhiSheng, Z., MingShan, H. and BaoZhong, S. (2014). Effect of different packing on quality changes of hot boning beef during storage. Journal of Agricultural Science and Technology (Beijing), 16(4), 102-108.

Fernandez, M. I., and Woodward, B. W. (1999). Comparison of conventional and organic beef production systems I. feedlot performance and production costs. Livestock Production Science, 61(2), 213-223.

Font-i-Furnols, M., \& Luis Guerrero, L. (2014). Consumer preference, behavior and perception about meat and meat products: An overview. Meat Science, 98(3), 361-371.

Geesink, G., Robertson, J., and Ball, A. (2015). The effect of retail packaging method on objective and consumer assessment of beef quality traits. Meat Science, 104, 85-89.

Giraud, G., and Amblard, C. (2003). What does traceability mean for beef meat consumer? Sciences des Aliments, 23(1), 40-46.

Gopal, P. R. C., and Thakkar, J. (2016). Analysing critical success factors to implement sustainable supply chain practices in Indian automobile industry: A case $\begin{array}{lllll}\text { study. Production } \quad \text { Planning } \quad \& \quad \text { Control, } & \text { DOI: }\end{array}$ http://dx.doi.org/10.1080/09537287.2016.1173247

Gorane, S. J., and Kant, R. (2013). Supply chain management: Modelling the enablers using ISM and fuzzy MICMAC approach. International Journal of Logistics Systems and Management, 16(2), 147-166.

Grebitus, C., Steiner, B., and Veeman, M. (2013). Personal values and decision making: evidence from Environmental footprint labeling in Canada. American Journal of Agricultural Economics, 95(2), 397-403. DOI: 10.1093/ajae/aas109

Grobbel, J. P., Dikeman, M. E., Hunt, M. C., and Milliken, G. A. (2008). Effects of packaging atmospheres on beef instrumental tenderness, fresh color stability, and internal cooked color. Journal of Animal Science, 86(5), 1191-1199. 
Grunert, K. (1997). What's in a steak? A cross-cultural study on the quality perception of beef. Food Quality and Preference, 8(3), 157-174. DOI: 10.1016/S0950-3293(96)00038-9

Grunert, K. G. (2005). Food quality and safety: consumer perception and demand. European Review of Agricultural Economics, 32(3), 369-391. DOI: 10.1093/eurrag/jbi011

Grunert, K. G. (2011). Sustainability in the food sector: A consumer behaviour perspective. International Journal on Food System Dynamics, 2(3), 207-218. DOI: http://dx.doi.org/10.18461/ijfsd.v2i3.232

Grunert, K. G., Bredahl, L., and Brunsø, K. (2004). Consumer perception of meat quality and implications for product development in the meat sector-a review. Meat Science, 66(2), 259-272. DOI: 10.1016/S0309-1740(03)00130-X

Guarddon, M., Miranda, J. M., Rodríguez, J. A., Vázquez, B. I., Cepeda, A., and Franco, C. M. (2014). Quantitative detection of tetracycline-resistant microorganisms in conventional and organic beef, pork and chicken meat. CyTA-Journal of Food, 12(4), 383-388.

Guide to Shopping for Rare Breed Beef. Taste Tradition Direct. Retrieved on 28 December, 2016 from https://tastetraditiondirect.co.uk/guide-shopping-rare-breed-beef/

Guzek, D., Głąbska, D., Gutkowska, K., Wierzbicki, J., Woźniak, A., and Wierzbicka, A. (2015). Analysis of the factors creating consumer attributes of roasted beef steaks. Animal Science Journal, 86(3), 333-339.

Gwin, L. (2009). Scaling-up sustainable livestock production: Innovation and challenges for grass-fed beef in the US. Journal of Sustainable Agriculture, 33(2), 189-209.

Haleem, A., Sushil, Qadri, M. A., and Kumar, S. (2012). Analysis of critical success factors of world-class manufacturing practices: an application of interpretative structural modelling and interpretative ranking process. Production Planning \& Control, 23(10-11), 722-734.

Hartmann, M., Klink, J., \& Simons, J. (2015). Cause related marketing in the German retail sector: Exploring the role of consumers' trust. Food Policy, 52, 108-114.

Hashem, I. A. T., Yaqoob, I., Anuar, N. B., Mokhtar, S., Gani, A., and Khan, S. U. (2015). The rise of "big data" on cloud computing: Review and open research issues. Information Systems, 47, 98-115.

Hawkes, C. (2004). Marketing food to children: The global regulatory environment. Geneva, Switzerland: World Health Organization.

He, W., Zha, S., and Li, L. (2013). Social media competitive analysis and text mining: A case study in the pizza industry. International Journal of Information Management, 33(3), 464472.

Henchion, M. M., McCarthy, M., \& Resconi, V. C. (2017). Beef quality attributes: A systematic review of consumer perspectives. Meat Science, 128, 1-7.

Hobbs, J.E., (1996). A transaction cost analysis of quality, traceability and animal welfare issues in UK beef retailing. British Food Journal, 98(6), 16-26.

Hocquette, J. F., Botreau, R., Legrand, I., Polkinghorne, R., Pethick, D. W., Lherm, M., Picard, B., Doreau, M. \& Terlouw, E. M. C. (2014). Win-win strategies for high beef quality, consumer satisfaction, and farm efficiency, low environmental impacts and improved animal welfare. Animal Production Science, 54(10), 1537-1548.

Hocquette, J. F., Bauchart, D., Micol, D., Polkinghorne, R., and Picard, B. (2015). 11 Beef Quality. Meat Quality: Genetic and Environmental Factors, 333. 
Huffman, K.L., Miller, M.F., Hoover, L.C., Wu, C.K., Brittin, H.C., and Ramsey, C.B. (1996). Effect of beef tenderness on consumer satisfaction with steaks consumed in the home and restaurant. Journal of Animal Science, 74, 91-97.

Hughes, D. L., Dwivedi, Y. K., Rana, N. P., and Simintiras, A. C. (2016). Information systems project failure-analysis of causal links using interpretive structural modelling. Production Planning \& Control, 27(16), 1313-1333.

Hughner, R. S., McDonagh, P., Prothero, A., Shultz, C. J., and Stanton, J. (2007). Who are organic food consumers? A compilation and review of why people purchase organic food. Journal of Consumer Behaviour, 6(2-3), 94-110. DOI: 10.1002/cb.210

Issanchou, S. (1996). Consumer expectations and perceptions of meat and meat product quality. Meat Science, 43, 5-19. DOI: 10.1016/0309-1740(96)00051-4

Jeyamkondan, S., Jayas, D. S., and Holley, R. A. (2000). Review of centralized packaging systems for distribution of retail-ready meat. Journal of Food Protection, 63(6), 796-804.

Jung, T., Ineson, E. M., Kim, M., and Yap, M. H. (2015). Influence of festival attribute qualities on Slow Food tourists' experience, satisfaction level and revisit intention The case of the Mold Food and Drink Festival. Journal of Vacation Marketing, 21(3), 277288.

Kahl, J., Bodroza-Solarov, M., Busscher, N., Hajslova, J., Kneifel, W., Kokornaczyk, M. O., ... and Stolz, P. (2014). Status quo and future research challenges on organic food quality determination with focus on laboratory methods. Journal of the Science of Food and Agriculture, 94(13), 2595-2599.

Katal, A., Wazid, M., and Goudar, R. H. (2013). Big data: issues, challenges, tools and good practices. 2013 Sixth International Conference on Contemporary Computing (IC3), 404409.

Kerry, J. P., O’grady, M. N., and Hogan, S. A. (2006). Past, current and potential utilisation of active and intelligent packaging systems for meat and muscle-based products: A review. Meat Science, 74(1), 113-130. DOI: 10.1016/j.meatsci.2006.04.024

Killinger, K. M., Calkins, C. R., Umberger, W. J., Feuz, D. M., and Eskridge, K. M. (2004a). Consumer sensory acceptance and value for beef steaks of similar tenderness, but differing in marbling level. Journal of Animal Science, 82(11), 3294-3301.

Killinger, K. M., Calkins, C. R., Umberger, W. J., Feuz, D. M., and Eskridge, K. M. (2004b). A comparison of consumer sensory acceptance and value of domestic beef steaks and steaks from a branded, Argentine beef program. Journal of Animal Science, 82(11), 33023307.

Koohmaraie, M., \& Geesink, G. H. (2006). Contribution of postmortem muscle biochemistry to the delivery of consistent meat quality with particular focus on the calpain system. Meat Science, 74(1), 34-43.

Kotler, P., and Armstrong, G. (2006). Principles of marketing (11th ed.). Upper Saddle River, NJ: Prentice Hall.

Krystallis, A., Chryssochoidis, G., and Scholderer, J. (2007). Consumer-perceived quality in 'traditional' food chains: The case of the Greek meat supply chain. Appetite, 48(1), 5468. DOI: 10.1016/j.appet.2006.06.003

Kukowski, A. C., Maddock, R. J., Wulf, D. M., Fausti, S. W., and Taylor, G. L. (2005). Evaluating consumer acceptability and willingness to pay for various beef chuck muscles. Journal of Animal Science, 83(11), 2605-2610. 
Kumar, S., Luthra, S., Govindan, K., Kumar, N., and Haleem, A. (2016). Barriers in green lean six sigma product development process: An ISM approach. Production Planning \& Control, 1-17. DOI: http://dx.doi.org/10.1080/09537287.2016.1165307

Lähteenmäki, L. (2013). Claiming health in food products. Food Quality and Preference, 27(2), 196-201. DOI: 10.1016/j.foodqual.2012.03.006

Lanz, B., Wurlod, J. D., Panzone, L., and Swanson, T. (2014). Clean substitutes and the effectiveness of Carbon Footprint Labels vs. Pigovian Subsidies: Evidence from a Field Experiment (No. 32-2014). Centre for International Environmental Studies, The Graduate Institute.

Lawson, R. (2002). Consumer knowledge structures: Background issues and introduction. Psychology \& Marketing, 19(6), 447-455. DOI: 10.1002/mar.10019

Lee, J. Y., Han, D. B., Nayga, R. M., and Lim, S. S. (2011). Valuing traceability of imported beef in Korea: an experimental auction approach*. Australian Journal of Agricultural and Resource Economics, 55(3), 360-373. DOI: 10.1111/j.1467-8489.2011.00553.x

Legako, J. F., Brooks, J. C., O'Quinn, T. G., Hagan, T. D. J., Polkinghorne, R., Farmer, L. J., and Miller, M. F. (2015). Consumer palatability scores and volatile beef flavor compounds of five USDA quality grades and four muscles. Meat Science, 100, 291-300.

Levin, I. P., and Johnson, R. D. (1984). Estimating price-quality tradeoffs using comparative judgments. Journal of Consumer Research, 593-600.

Lewis, K. E., Grebitus, C., Colson, G., \& Hu, W. (2016). German and British Consumer Willingness to Pay for Beef Labeled with Food Safety Attributes. Journal of Agricultural Economics

Liang, P. W., and Dai, B. R. (2013). Opinion mining on social media data. 14th International Conference on Mobile Data Management (MDM), 2, 91-96.

Lichtenstein, D. R., Ridgway, N. M., and Netemeyer, R. G. (1993). Price perceptions and consumer shopping behavior: a field study. Journal of Marketing Research, 234-245. DOI: $10.2307 / 3172830$

Liu, R., Pieniak, Z., \& Verbeke, W. (2013). Consumers' attitudes and behaviour towards safe food in China: A review. Food Control, 33(1), 93-104.

Liu, S., and Ma, T. (2016). Research on construction of the quality and safety of agricultural products traceability based on multisided platform-taking beef quality and safety traceability in Xinjiang as an example. Proceedings of the 2015 International Conference on Food Hygiene, Agriculture and Animal Science.

Mani, V., Agrawal, R., and Sharma, V. (2015a). Social sustainability in the supply chain: Analysis of enablers. Management Research Review, 38(9), 1016-1042.

Mani, V., Agrawal, R., and Sharma, V. (2015b). Impediments to social sustainability adoption in the supply chain: An ISM and MICMAC analysis in Indian manufacturing industries. Global Journal of Flexible Systems Management, 1-22.

Marian, L., Chrysochou, P., Krystallis, A., and Thøgersen, J. (2014). The role of price as a product attribute in the organic food context: An exploration based on actual purchase data. Food Quality and Preference, 37, 52-60. DOI: 10.1016/j.foodqual.2014.05.001

Mashov, Y., (2009). Increase eco-efficiency, reduce food waste by choosing VSP(SKIN) packaging solutions. Retrieved from https://www.linkedin.com/pulse/increase-ecoefficiency-reduce-food-waste-choosing-vspskin-yan-mashov on 20th December 2016. 
Mason, M. C., and Nassivera, F. (2013). A conceptualization of the relationships between quality, satisfaction, behavioral intention, and awareness of a festival. Journal of Hospitality Marketing \& Management,22 (2), 162-182.

Mason, M. C., and Paggiaro, A. (2010). Celebrating local products: The role of food events. Journal of Foodservice Business Research, 12, 364-383.

Mathiyazhagan, K., Govindan, K., NoorulHaq, A., and Geng, Y. (2013). An ISM approach for the barrier analysis in implementing green supply chain management. Journal of Cleaner Production, 47, 283-297.

McAfee, A. J., McSorley, E. M., Cuskelly, G. J., Moss, B. W., Wallace, J. M., Bonham, M. P., and Fearon, A. M. (2010). Red meat consumption: An overview of the risks and benefits. Meat Science, 84(1), 1-13. DOI: 10.1016/j.meatsci.2009.08.029

Mcllveen, H., and Buchanan, J. (2001). The impact of sensory factors on beef purchase and consumption. Nutrition \& Food Science, 31(6), 286-292. DOI: http://dx.doi.org/10.1108/00346650110409119

Meat Promotion Wales, (2012). Reducing waste in the beef and lamb supply chains. $\begin{array}{lllll}\text { Retrieved on } 28 & \text { December, } & 2016\end{array}$ https://www.google.co.uk/url?sa=t\&rct=j\&q=\&esrc=s\&source=web\&cd=1\&cad=rja\&uac $\mathrm{t}=8 \&$ ved=0ahUKEwigwprKroLRAhUMd1AKHTVmABIQFggiMAA\&url=http $\% 3 \mathrm{~A} \% 2$ F\%2Fhccmpw.org.uk\%2Findex.php\%2Ftools\%2Frequired\%2Ffiles\%2Fdownload\%3FfI D\%3D4350\&usg=AFQjCNFJc0kILGN9IrXfqpnMlbFQCUCoWw\&bvm=bv.142059868, d.ZWM

Menozzi, D., Halawany-Darson, R., Mora, C., and Giraud, G. (2015). Motives towards traceable food choice: A comparison between French and Italian consumers. Food Control, 49, 40-48.

Morales, L., Griffith, G., Wright, V. Fleming, E., Umberger, W., Hoang N. (2013). Variables affecting the propensity to buy branded beef among groups of Australian beef buyers Meat Science, 94 (2), 239-246

Mesías, F. J., Martínez-Carrasco, F., Martínez, J. M., and Gaspar, P. (2011). Functional and organic eggs as an alternative to conventional production: a conjoint analysis of consumers' preferences. Journal of the Science of Food and Agriculture, 91(3), 532-538. DOI: $10.1002 /$ jsfa.4217

Mishra, N., \& Singh, A. (2016). Use of twitter data for waste minimisation in beef supply chain. Annals of Operations Research, 1-23.

Napolitano, F., Braghieri, A., Piasentier, E., Favotto, S., Naspetti, S., and Zanoli, R. (2010). Effect of information about organic production on beef liking and consumer willingness to pay. Food Quality and Preference, 21(2), 207-212. DOI: 10.1016/j.foodqual.2009.08.007

Nash, H. A. (2009). The European Commission's sustainable consumption and production and sustainable industrial policy action plan. Journal of Cleaner Production, 17(4), 496498. DOI: $10.1016 /$ j.jclepro.2008.08.020

Nayga, R. M. (2008). Nutrition, obesity and health: policies and economic research challenges. European Review of Agricultural Economics, 35(3), 281-302. DOI: 10.1093/erae/jbn013

Neely, T. R., Lorenzen, C. L., Miller, R. K., Tatum, J. D., Wise, J. W., Taylor, J. F., ... and Savell, J. W. (1998). Beef customer satisfaction: role of cut, USDA quality grade, and city on in-home consumer ratings. Journal of Animal Science, 76(4), 1027-1033. 
Nielsen, B. K., and Thamsborg, S. M. (2005). Welfare, health and product quality in organic beef production: A Danish perspective. Livestock Production Science, 94(1), 41-50.

Oliver, C. (2012). Artisan beef: An alternative view of beef quality. Animal Frontiers, 2(4), 68-73.

Onozaka, Y., Nurse, G., and McFadden, D. T. (2010). Local food consumers: how motivations and perceptions translate to buying behavior. Choices, 25(1), 1-6. O'Quinn, T. G., Woerner, D. R., Engle, T. E., Chapman, P. L., Legako, J. F., Brooks, J. C., ... and Tatum, J. D. (2016). Identifying consumer preferences for specific beef flavor characteristics in relation to cattle production and postmortem processing parameters. Meat Science, 112, 90-102. DOI: 10.1016/j.meatsci.2015.11.001

Owczarek-Fendor, A., Vermeulen, A., Van Bree, I., Eriksson, M., Lescouhier, S., De Smet, S., ... and Devlieghere, F. (2014). Effect of muscle, ageing time and modified atmosphere packaging conditions on the colour, oxidative and microbiological stability of packed beef. International Journal of Food Science \& Technology, 49(4), 1090-1098.

Pethick, D. W., Ball, A. J., Banks, R. G., \& Hocquette, J. F. (2011). Current and future issues facing red meat quality in a competitive market and how to manage continuous improvement. Animal Production Science, 51(1), 13-18.

Profita, C., (2012). Which Is Greener: Grass-Fed or Grain-Fed Beef? Rcotrope. Retrieved from http://www.opb.org/news/blog/ecotrope/which-is-greener-grass-fed-or-grain-fedbeef/ on 20th December 2016.

Purohit, J. K., Mittal, M. L., Mittal, S., and Sharma, M. K. (2016). Interpretive structural modeling-based framework for mass customisation enablers: An Indian footwear case. Production Planning \& Control, 1-13.

Quelch, J. A. (1983). It's time to make trade promotion more productive. Harvard Business Review, 61(3), 130-136.

Qureshi, M. N., Kumar, D., and Kumar, P. (2008). An integrated model to identify and classify the key criteria and their role in the assessment of 3PL services providers. Asia Pacific Journal of Marketing and Logistics, 20(2), 227-249.

Realini, C. E., i Furnols, M. F., Sañudo, C., Montossi, F., Oliver, M. A., and Guerrero, L. (2013). Spanish, French and British consumers' acceptability of Uruguayan beef, and consumers' beef choice associated with country of origin, finishing diet and meat price. Meat science, 95(1), 14-21.

Reicks, A. L., Brooks, J. C., Garmyn, A. J., Thompson, L. D., Lyford, C. L., and Miller, M. F. (2011). Demographics and beef preferences affect consumer motivation for purchasing fresh beef steaks and roasts. Meat Science, 87(4), 403-411.

Rezaei, S. (2015). Segmenting consumer decision-making styles (CDMS) toward marketing practice: A partial least squares (PLS) path modeling approach. Journal of Retailing and Consumer Services, 22, 1-15.

Ricke, S. C. (2012). Organic meat production and processing (Vol. 53). John Wiley \& Sons. Rimal, A. (2005). Meat labels: consumer attitude and meat consumption pattern. International Journal of Consumer Studies, 29(1), 47-54. DOI: 10.1111/j.1470-6431.2005.00374.x

Robbins, K., Jensen, J., Ryan, K. J., Homco-Ryan, C., McKeith, F. K., and Brewer, M. S. (2003). Consumer attitudes towards beef and acceptability of enhanced beef. Meat Science, 65(2), 721-729. 
Röös, E., and Tjärnemo, H. (2011). Challenges of carbon labelling of food products: a consumer research perspective. British Food Journal, 113(8), 982-996. DOI: http://dx.doi.org/10.1108/00070701111153742

Rossiter, J. R., and Percy, L. (1998). Advertising communication and promotion management (2nd ed.), New York, NY: McGraw-Hill.

Ruviaro, C. F., de Léis, C. M., Lampert, V. D. N., Barcellos, J. O. J., and Dewes, H. (2015). Carbon footprint in different beef production systems on a southern Brazilian farm: a case study. Journal of Cleaner Production, 96, 435-443.

Savadkoohi, S., Hoogenkamp, H., Shamsi, K., and Farahnaky, A. (2014). Color, sensory and textural attributes of beef frankfurter, beef ham and meat-free sausage containing tomato pomace. Meat science, 97(4), 410-418.

Savell, J. W., Cross, H. R., Francis, J. J., Wise, J. W., Hale, D. S., Wilkes, D. L., and Smith, G. C. (1989). National consumer retail beef study: Interaction of trim level, price and grade on consumer acceptance of beef steaks and roasts. Journal of Food Quality, 12(4), 251-274.

Saxena, J. P., and Vrat, P. (1992). Scenario building: a critical study of energy conservation in the Indian cement industry. Technological Forecasting and Social Change, 41(2), 121146.

Silvennoinen, K., Katajajuuri, J. M., Hartikainen, H., Heikkilä, L., \& Reinikainen, A. (2014). Food waste volume and composition in Finnish households. British Food Journal, 116(6), 1058-1068.

Simchi-Levi, D. 2014. OM forum-OM research: From problem-driven to data-driven research. Manufacturing \& Service Operations Management, 16(1), 2-10.

Simeon, M. I., and Buonincontri, P. (2011). Cultural events as a marketing tool: The case of the Ravello Festival on the Italian Amalfi coast. Journal of Hospitality Marketing \& Management, 20, 385-406.

Simons, D., Francis, M., Bourlakis, M., and Fearne, A. (2003). Identifying the determinants of value in the UK red meat industry: A value chain analysis approach. Journal on Chain and Network Science, 3(2), 109-121.

Sindhu, S., Nehra, V., and Luthra, S. (2016). Identification and analysis of barriers in implementation of solar energy in Indian rural sector using integrated ISM and fuzzy MICMAC approach. Renewable and Sustainable Energy Reviews, 62, 70-88.

Singh, A., Mishra, N., Ali, S. I., Shukla, N., and Shankar, R. (2015). Cloud computing technology: Reducing carbon footprint in beef supply chain. International Journal of Production Economics, 164, 462-471. DOI: 10.1016/j.ijpe.2014.09.019

Sitz, B. M., Calkins, C. R., Feuz, D. M., Umberger, W. J., and Eskridge, K. M. (2005). Consumer sensory acceptance and value of domestic, Canadian, and Australian grass-fed beef steaks. Journal of Animal Science, 83(12), 2863-2868.

Squires, L., Juric, B., and Bettina Cornwell, T. (2001). Level of market development and intensity of organic food consumption: cross-cultural study of Danish and New Zealand consumers. Journal of Consumer Marketing, 18(5), 392-409. DOI: http://dx.doi.org/10.1108/07363760110398754.

Średnicka-Tober, D., Barański, M., Seal, C., Sanderson, R., Benbrook, C., Steinshamn, H., ... and Cozzi, G. (2016). Composition differences between organic and conventional meat: 
A systematic literature review and meta-analysis. British Journal of Nutrition, 115(6), 994-1011.

Suman, S. P., Nair, M. N., Joseph, P., and Hunt, M. C. (2016). Factors influencing internal color of cooked meats. Meat science. DOI: http://dx.doi.org/10.1016/j.meatsci.2016.04.006.

Ubilava, D., and Foster, K. (2009). Quality certification vs. product traceability: Consumer preferences for informational attributes of pork in Georgia. Food Policy, 34(3), 305-310. DOI: 10.1016/j.foodpol.2009.02.002.

Van Doorn, J., \& Verhoef, P. C. (2015). Drivers of and barriers to organic purchase behavior. Journal of Retailing, 91(3), 436-450.

Van Rijswijk, W., and Frewer, L. J. (2008b). Consumer perceptions of food quality and safety and their relation to traceability. British Food Journal,110(10), 1034-1046.

van Rijswijk, W., Frewer, L. J., Menozzi, D., and Faioli, G. (2008a). Consumer perceptions of traceability: A cross-national comparison of the associated benefits. Food Quality and Preference, 19(5), 452-464.

Van Wezemael, L., Caputo, V., Nayga, R. M., Chryssochoidis, G., and Verbeke, W. (2014). European consumer preferences for beef with nutrition and health claims: A multicountry investigation using discrete choice experiments. Food Policy, 44, 167-176. DOI: 10.1016/j.foodpol.2013.11.006.

Van Wezemael, L., Verbeke, W., de Barcellos, M. D., Scholderer, J., and Perez-Cueto, F. (2010). Consumer perceptions of beef healthiness: results from a qualitative study in four European countries. BMC Public Health,10(1), 1-10. DOI: 10.1186/1471-2458-10-342.

Verbeke, W., and Ward, R. W. (2006). Consumer interest in information cues denoting quality, traceability and origin: An application of ordered probit models to beef labels. Food Quality and Preference, 17(6), 453-467.

Verbeke, W., De Smet, S., Vackier, I., Van Oeckel, M. J., Warnants, N., and Van Kenhove, P. (2005). Role of intrinsic search cues in the formation of consumer preferences and choice for pork chops. Meat Science, 69(2), 343-354. DOI: 10.1016/j.meatsci.2004.08.005

Verbeke, W., Van Wezemael, L., de Barcellos, M. D., Kügler, J. O., Hocquette, J. F., Ueland, $\varnothing$., and Grunert, K. G. (2010). European beef consumers' interest in a beef eating-quality guarantee: insights from a qualitative study in four EU countries. Appetite, 54(2), 289296. DOI: 10.1016/j.appet.2009.11.013

Vermeir, I., and Verbeke, W. (2006). Sustainable food consumption: Exploring the consumer "attitude-behavioral intention" gap. Journal of Agricultural and Environmental ethics, 19(2), 169-194. DOI: 10.1007/s10806-005-5485-3

Viljoen, H. F., De Kock, H. L., and Webb, E. C. (2002). Consumer acceptability of dark, firm and dry (DFD) and normal pH beef steaks. Meat Science, 61(2), 181-185.

Vlaeminck, P., Jiang, T., and Vranken, L. (2014). Food labeling and eco-friendly consumption: Experimental evidence from a Belgian supermarket. Ecological Economics, 108, 180-190. DOI: 10.1016/j.ecolecon.2014.10.019

Völckner, F., and Hofmann, J. (2007). The price-perceived quality relationship: A metaanalytic review and assessment of its determinants. Marketing Letters, 18(3), 181-196. DOI: $10.1007 / \mathrm{s} 11002-007-9013-2$ 
Weber, C. L., and Matthews, H. S. (2008). Food-miles and the relative climate impacts of food choices in the United States. Environmental Science \& Technology, 42(10), 35083513.

Yamoah, F. A., and Yawson, D. E. (2014). Assessing supermarket food shopper reaction to horsemeat scandal in the UK. International Review of Management and Marketing, 4(2), 98-107.

Yiridoe, E. K., Bonti-Ankomah, S., and Martin, R. C. (2005). Comparison of consumer perceptions and preference toward organic versus conventionally produced foods: a review and update of the literature. Renewable Agriculture and Food Systems, 20(4), 193-205.

Zakrys, P. I., O’Sullivan, M. G., Allen, P., and Kerry, J. P. (2009). Consumer acceptability and physiochemical characteristics of modified atmosphere packed beef steaks. Meat science, 81(4), 720-725. DOI: 10.1016/j.meatsci.2008.10.024.

Załęcka, A., Bügel, S., Paoletti, F., Kahl, J., Bonanno, A., Dostalova, A., and Rahmann, G. (2014). The influence of organic production on food quality-research findings, gaps and future challenges. Journal of the Science of Food and Agriculture, 94(13), 2600-2604.

Zanoli, R., Scarpa, R., Napolitano, F., Piasentier, E., Naspetti, S., and Bruschi, V. (2013). Organic label as an identifier of environmentally related quality: A consumer choice experiment on beef in Italy. Renewable Agriculture and Food Systems, 28(01), 70-79.

Zhang, C., Bai, J., and Wahl, T. I. (2012). Consumers' willingness to pay for traceable pork, milk, and cooking oil in Nanjing, China. Food Control, 27(1), 21-28. DOI: 10.1016/j.foodcont.2012.03.001

Zikopoulos, P., and Eaton, C. (2011). Understanding big data: Analytics for enterprise class hadoop and streaming data. McGraw-Hill Osborne Media. 


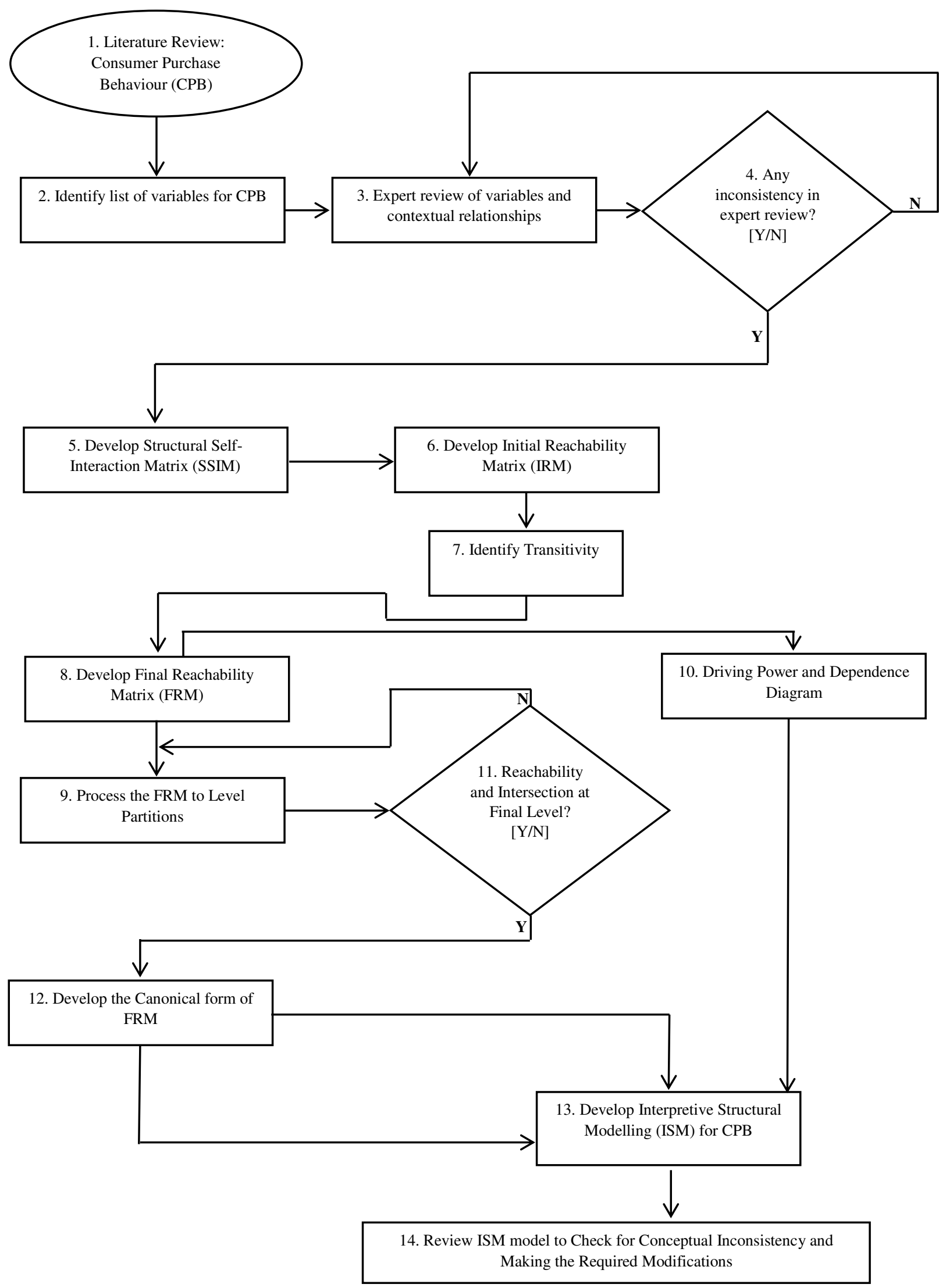




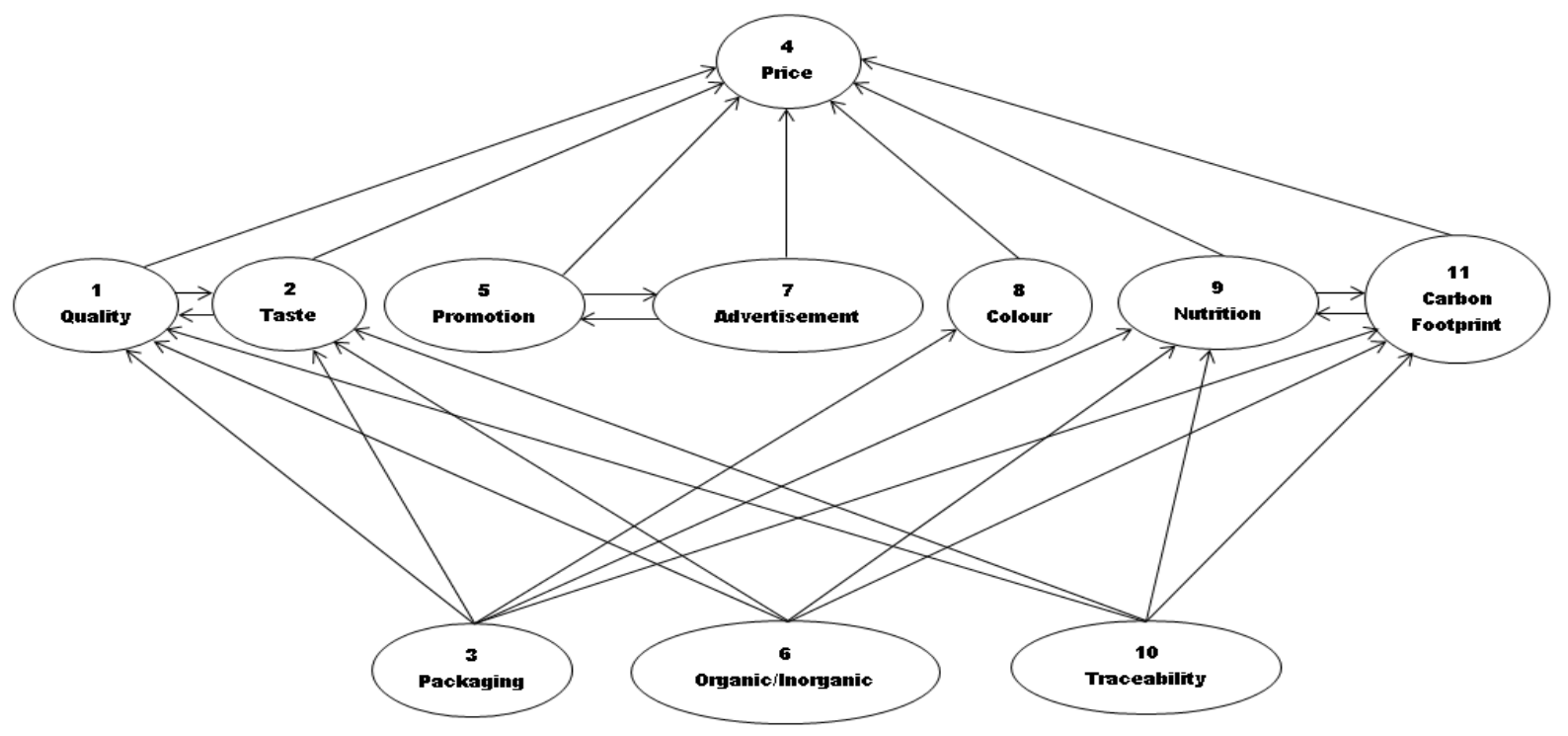

Figure 2. ISM Model

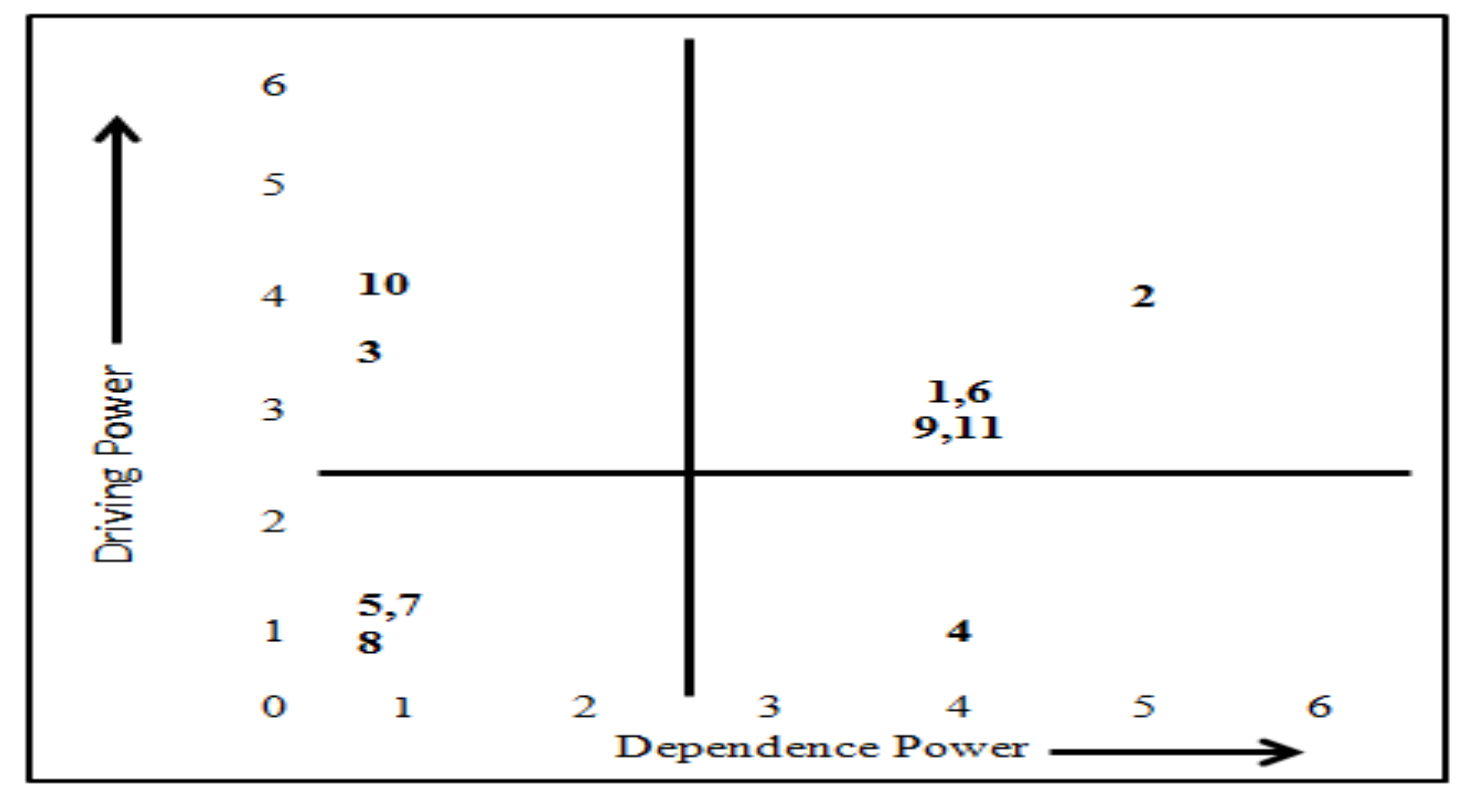

Figure 3. Cluster of variables 


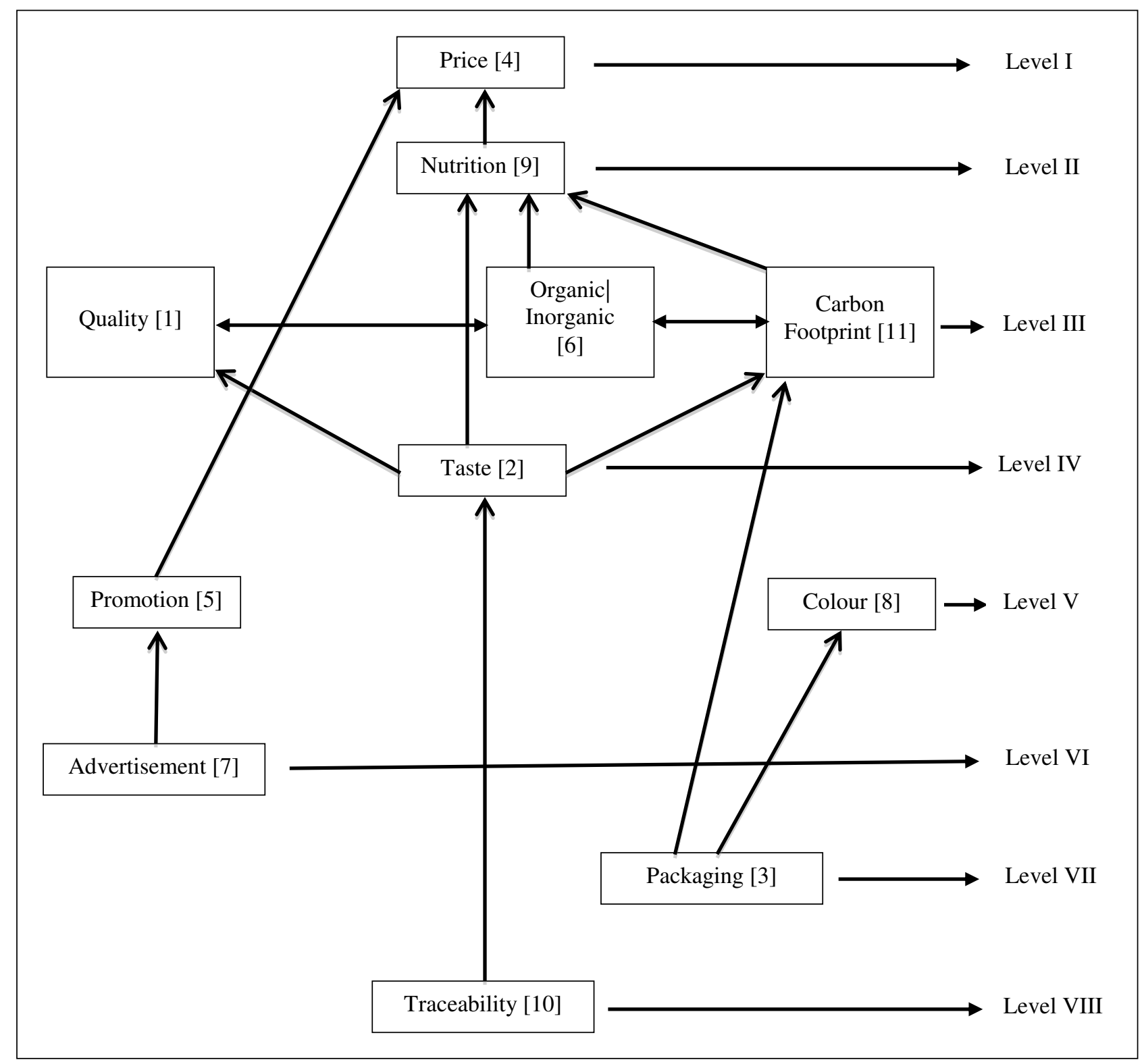

Figure 4. Integrated ISM Model 
Table 1 Keywords used for extracting research articles from prominent databases

\begin{tabular}{|c|c|}
\hline S. No. & Keywords \\
\hline 1. & $\begin{array}{l}\text { Priority OR Attitude OR Perception OR Intention OR Behaviour AND Customer AND Beef OR } \\
\text { Steak }\end{array}$ \\
\hline 2. & Expectations OR Experience AND Beef OR Steak AND Consumer \\
\hline 3. & Quality cues OR quality attributes AND Beef OR Steak AND Consumer \\
\hline 4. & Preference OR Choices AND Beef OR Steak AND Consumer \\
\hline 5. & Like OR Dislike OR Prefer AND Beef OR Steak AND Consumer \\
\hline 6. & Driver OR Enabler OR Purchase behaviour AND Beef OR Steak AND Consumer \\
\hline 7. & $\begin{array}{l}\text { Carbon footprint OR Sustainability OR Greenhouse gases OR Emissions OR Global Warming AND } \\
\text { Beef OR Steak AND Consumer }\end{array}$ \\
\hline 8. & Colour OR Discoloured OR Grey OR Red OR Brown AND Beef OR Steak AND Consumer \\
\hline 9. & Price OR Cost OR Expensive OR Cheap AND Beef OR Steak AND Consumer \\
\hline 10. & Taste OR Flavour OR Delicious AND Beef OR Steak AND Consumer \\
\hline 11. & Advertisement OR Campaign OR Media OR Marketing AND Beef OR Steak AND Consumer \\
\hline 12. & $\begin{array}{l}\text { Nutrition OR Fat OR Protein OR Vitamins OR Minerals OR Healthy AND Beef OR Steak AND } \\
\text { Consumer }\end{array}$ \\
\hline 13. & Packaging OR MAP OR VSP AND Beef OR Steak AND Consumer \\
\hline 14. & Organic OR Premium OR Animal Welfare AND Beef OR Steak AND Consumer \\
\hline 15. & Promotion OR Deal OR Offer OR Bargain AND Beef OR Steak AND Consumer \\
\hline 16. & Traceability OR Labelling OR Food safety OR Origin AND Beef OR Steak AND Consumer \\
\hline 17. & Smell OR Odour OR Aroma AND Beef OR Steak AND Consumer \\
\hline 18. & Tenderness OR Chewy OR Maturation AND Beef OR Steak AND Consumer \\
\hline
\end{tabular}


Table 2. List of variables influencing consumer's beef purchasing behaviour

\begin{tabular}{|c|c|c|}
\hline S. No. & Variables & Sources \\
\hline 1 & Quality & $\begin{array}{l}\text { Banović et al. (2009); Becker (2000); Brunsø et al. (2005); Acebron \& } \\
\text { Dopico, (2000); Grunert et al. (2004); Krystalli et al. (2007); Verbeke et } \\
\text { al. (2010); Koohmaraie and Geesink, } 2006\end{array}$ \\
\hline 2 & Taste & $\begin{array}{l}\text { Killinger et al. (2004a); Killinger et al. (2004b); McIlveen \& Buchanan } \\
\text { (2001); Oliver (2012); O'Quinn et al, (2016); Sitz et al. (2005) }\end{array}$ \\
\hline 3 & Packaging & $\begin{array}{l}\text { Zakrys et al. (2009); Kerry et al., 2006; Grobbel et al. (2008); Carpenter et } \\
\text { al. (2001); Verbeke et al. (2005); Bernués et al. (2003) }\end{array}$ \\
\hline 4 & Price & $\begin{array}{l}\text { Acebrón \& Dopico (2000); Hocquette et al. (2015); Kukowski et al. } \\
\text { (2005); Liu \& Ma (2016); Marian et al. (2014); Völckner \& Hofmann } \\
\text { (2007) }\end{array}$ \\
\hline 5 & Promotion & $\begin{array}{l}\text { Cairns et al. (2009); Eertmans et al. (2001); Elliott (2016); Hawkes } \\
\text { (2004); Kotler \& Armstrong (2006) }\end{array}$ \\
\hline 6 & Organic/inorganic & $\begin{array}{l}\text { Bartels \& Reinders (2010); Bravo et al. (2013); Guarddon et al. (2014); } \\
\text { Hughner et al. (2007); Mesías et al. (2011); Napolitano et al. (2010); } \\
\text { Ricke (2012); Squires et al. (2001); Średnicka-Tober et al. (2016) }\end{array}$ \\
\hline 7 & Advertisement & $\begin{array}{l}\text { De Chernatony and McDonald (2003); Jung et al. (2015); Mason \& } \\
\text { Nassivera (2013); Mason \& Paggiaro (2010); Simeon \& Buonincontri } \\
\text { (2011) }\end{array}$ \\
\hline 8 & Colour & $\begin{array}{l}\text { Guzek et al. (2015); Jeyamkondan et al. (2000); Kerry et al. (2006); } \\
\text { McIlveen \& Buchanan, (2001); Realini et al. (2015); Savadkoohi et al. } \\
\text { (2014); Suman et al. (2016); Viljoen et al. (2002); Font-i-Furnols and Luis } \\
\text { Guerrero, (2014) }\end{array}$ \\
\hline 9 & Nutrition (Fat label) & $\begin{array}{l}\text { Barreiro-Hurlé et al. (2009); da Fonseca \& Salay (2008); Lähteenmäki } \\
\text { (2013); Lawson (2002); McAfee et al. (2010); Nayga (2008); Rimal } \\
\text { (2005); van Wezemael et al. (2010); van Wezemael et al. (2014); De Smet } \\
\text { and Vossen, (2016); Egan et al., (2001); Pethick et al., (2011) }\end{array}$ \\
\hline 10 & Traceability & $\begin{array}{l}\text { Becker (2000); Bruns } \varnothing \text { et al. (2002); Clemens \& Babcock (2015); Giraud } \\
\& \text { Amblard (2003); Grunert (2005); Lee et al. (2011); Menozzi et al. } \\
\text { (2015); Ubilava \& Foster (2009); van Rijswijk \& Frewer (2008); van } \\
\text { Rijswijk et al. (2008a); Verbeke \& Ward (2006); Zhang et al. (2012) }\end{array}$ \\
\hline 11 & Carbon footprint & $\begin{array}{l}\text { Grebitus et al. (2013); Grunert (2011); Lanz et al. (2014); Nash (2009); } \\
\text { Onozaka et al. (2010); Röös \& Tjärnemo (2011); Singh et al. (2015); } \\
\text { Vermeir \& Verbeke (2006); Vlaeminck et al. (2014) }\end{array}$ \\
\hline
\end{tabular}


Table 3. Keywords used for extracting consumer tweets

\begin{tabular}{|c|c|c|c|}
\hline Beef\#disappointment & Beef\#Rotten & Beef\# rancid & Beef\#was very chewy \\
\hline Beef\#taste awful & Beef\#unhappy & Beef\#packaging blown & Beef\#was very fatty \\
\hline Beef\#Odd colour beef & Beef\#discoloured & Beef\#Plastic in beef & Beef\#Gristle in beef \\
\hline Beef\#complaint & Beef\#Beefgrey colour & Beef\#Oxidised beef & Beef\#Taste \\
\hline Beef\#complaint & Beef\#Beefgrey colour & Beef\#Oxidised beef & Beef\#Taste \\
\hline Beef\#Flavour & Beef\#Smell & Beef\#Rotten & Beef\#Funny colour \\
\hline Beef\#Horsemeat & Beef\#Customer support & Beef\#Bone & Beef\#Inedible \\
\hline Beef\#Mushy & Beef\#Skimpy & Beef\#Use by date & Beef\#Stingy \\
\hline Beef\#Grey colour & Beef\#Packaging & Beef\#Oxidised & Beef\#Odd colour \\
\hline Beef\#Gristle & Beef\#Fatty & Beef\#Green colour & Beef\#Lack of meat \\
\hline Beef\#Rubbery & Beef\#Suet & Beef\#Receipt & Beef\#Stop selling \\
\hline Beef\#Deal & Beef\#Bargain & Beef\#discoloured & Beef\#Dish \\
\hline Beef\#Stink & Beef\#Bin & Beef\#Goes off & Beef\#Rubbish \\
\hline Beef\#Delivery & Beef\#Scrummy & Beef\#Advertisement & Beef\#Promotion \\
\hline Beef\#Traceability & Beef\#Carbon footprint & Beef\#Nutrition & Beef\#Labelling \\
\hline Beef\#Price & Beef\#Organic/ Inorganic & Beef\#MAP packaging & Beef\#Tenderness \\
\hline
\end{tabular}

Table 4. Pearson Correlation Test of the Cluster Analysis (Partial Results)

\begin{tabular}{|c|l|l|c|}
\hline S. No. & Variable I & Variable II & P.C.C. Score \\
\hline 1 & Quality & Taste & 0.99 \\
\hline 2 & Promotion & Advertisement & 0.98 \\
\hline 3 & Quality & Nutrition & 0.92 \\
\hline 4 & Price & Nutrition & 0.95 \\
\hline 5 & Colour & Packaging & 0.95 \\
\hline 6 & Organic/ Inorganic & Quality & 0.95 \\
\hline 7 & Organic/inorganic & Carbon Footprint & 0.92 \\
\hline 8 & Price & Quality & 0.94 \\
\hline 9 & Organic/ Inorganic & Taste & 0.94 \\
\hline 10 & Packaging & Quality & 0.94 \\
\hline 11 & Quality & Carbon footprint & 0.95 \\
\hline 12 & Packaging & Price & 0.93 \\
\hline 13 & Price & Traceability & 0.96 \\
\hline 14 & Price & Promotion & 0.93 \\
\hline 15 & Price & Colour & 0.93 \\
\hline 16 & Price & Carbon footprint & 0.93 \\
\hline 17 & Packaging & Taste & 0.93 \\
\hline 18 & Price & Taste & 0.92 \\
\hline 19 & Quality & Traceability & 0.92 \\
\hline 20 & Price & Organic/inorganic & 0.94 \\
\hline
\end{tabular}

[Legend: P.C.C: Pearson Correlation Coefficient S. No.: Serial Number] 
Table 5. Structural Self-Interactional Matrix (SSIM)

\begin{tabular}{|c|c|c|c|c|c|c|c|c|c|c|c|}
\hline $\mathrm{V}[\mathrm{i} / \mathrm{j}]$ & 11 & 10 & 9 & 8 & 7 & 6 & 5 & 4 & 3 & 2 & 1 \\
\hline 1 & $\mathrm{X}$ & $\mathrm{A}$ & $\mathrm{X}$ & $\mathrm{O}$ & $\mathrm{O}$ & $\mathrm{A}$ & $\mathrm{O}$ & $\mathrm{V}$ & $\mathrm{A}$ & $\mathrm{X}$ & \\
\hline 2 & $\mathrm{O}$ & $\mathrm{O}$ & $\mathrm{O}$ & $\mathrm{O}$ & $\mathrm{O}$ & $\mathrm{A}$ & $\mathrm{O}$ & $\mathrm{V}$ & $\mathrm{A}$ & & \\
\hline 3 & $\mathrm{O}$ & $\mathrm{O}$ & $\mathrm{O}$ & $\mathrm{V}$ & $\mathrm{O}$ & $\mathrm{O}$ & $\mathrm{O}$ & $\mathrm{V}$ & & & \\
\hline 4 & $\mathrm{~A}$ & $\mathrm{~A}$ & $\mathrm{~A}$ & $\mathrm{~A}$ & $\mathrm{O}$ & $\mathrm{A}$ & $\mathrm{A}$ & & & & \\
\hline 5 & $\mathrm{O}$ & $\mathrm{O}$ & $\mathrm{O}$ & $\mathrm{O}$ & $\mathrm{X}$ & $\mathrm{O}$ & & & & & \\
\hline 6 & $\mathrm{X}$ & $\mathrm{O}$ & $\mathrm{O}$ & $\mathrm{O}$ & $\mathrm{O}$ & & & & & & \\
\hline 7 & $\mathrm{O}$ & $\mathrm{O}$ & $\mathrm{O}$ & $\mathrm{O}$ & & & & & & & \\
\hline 8 & $\mathrm{O}$ & $\mathrm{O}$ & $\mathrm{O}$ & & & & & & & & \\
\hline 9 & $\mathrm{O}$ & $\mathrm{O}$ & & & & & & & & & \\
\hline 10 & $\mathrm{O}$ & & & & & & & & & & \\
\hline 11 & & & & & & & & & & & \\
\hline
\end{tabular}

[Legend: [1] Quality, [2] Taste, [3] Packaging, [4] Price, [5] Promotion, [6] Organic/Inorganic, [7] Advertisement, [8] Colour, [9] Nutrition, [10] Traceability and [11] Carbon Footprint, V[i/j] = Variable i/Variable j]

Table 6. Initial Reachability Matrix

\begin{tabular}{|c|c|c|c|c|c|c|c|c|c|c|c|}
\hline $\mathrm{V}[\mathrm{i} / \mathrm{j}]$ & 1 & 2 & 3 & 4 & 5 & 6 & 7 & 8 & 9 & 10 & 11 \\
\hline 1 & 1 & 1 & 0 & 1 & 0 & 0 & 0 & 0 & 1 & 0 & 1 \\
\hline 2 & 1 & 1 & 0 & 1 & 0 & 0 & 0 & 0 & 0 & 0 & 0 \\
\hline 3 & 1 & 1 & 1 & 1 & 0 & 0 & 0 & 1 & 0 & 0 & 0 \\
\hline 4 & 0 & 0 & 0 & 1 & 0 & 0 & 0 & 0 & 0 & 0 & 0 \\
\hline 5 & 0 & 0 & 0 & 1 & 1 & 0 & 1 & 0 & 0 & 0 & 0 \\
\hline 6 & 1 & 1 & 0 & 1 & 0 & 1 & 0 & 0 & 0 & 0 & 1 \\
\hline 7 & 0 & 0 & 0 & 0 & 1 & 0 & 1 & 0 & 0 & 0 & 0 \\
\hline 8 & 0 & 0 & 0 & 1 & 0 & 0 & 0 & 1 & 0 & 0 & 0 \\
\hline 9 & 1 & 0 & 0 & 1 & 0 & 0 & 0 & 0 & 1 & 0 & 0 \\
\hline 10 & 1 & 0 & 0 & 1 & 0 & 0 & 0 & 0 & 0 & 1 & 0 \\
\hline 11 & 1 & 0 & 0 & 1 & 0 & 1 & 0 & 0 & 0 & 0 & 1 \\
\hline
\end{tabular}

[Legend: [1] Quality, [2] Taste, [3] Packaging, [4] Price, [5] Promotion, [6] Organic/Inorganic, [7] Advertisement, [8] Colour, [9] Nutrition, [10] Traceability and [11] Carbon Footprint, V[i/j] = Variable i/Variable j]

Table 7. Final Reachability Matrix

\begin{tabular}{|c|c|c|c|c|c|c|c|c|c|c|c|c|}
\hline $\mathrm{V}[\mathrm{i} / \mathrm{j}]$ & 1 & 2 & 3 & 4 & 5 & 6 & 7 & 8 & 9 & 10 & 11 & $\mathrm{DRP}$ \\
\hline 1 & 1 & 1 & 0 & 1 & 0 & $1^{*}$ & 0 & 0 & 1 & 0 & 1 & 6 \\
\hline 2 & 1 & 1 & 0 & 1 & 0 & 0 & 0 & 0 & $1^{*}$ & 0 & $1^{*}$ & 5 \\
\hline 3 & 1 & 1 & 1 & 1 & 0 & 0 & 0 & 1 & $1^{*}$ & 0 & $1^{*}$ & 7 \\
\hline 4 & 0 & 0 & 0 & 1 & 0 & 0 & 0 & 0 & 0 & 0 & 0 & 1 \\
\hline 5 & 0 & 0 & 0 & 1 & 1 & 0 & 1 & 0 & 0 & 0 & 0 & 3 \\
\hline 6 & 1 & 1 & 0 & 1 & 0 & 1 & 0 & 0 & $1^{*}$ & 0 & 1 & 6 \\
\hline 7 & 0 & 0 & 0 & $1^{*}$ & 1 & 0 & 1 & 0 & 0 & 0 & 0 & 3 \\
\hline 8 & 0 & 0 & 0 & 1 & 0 & 0 & 0 & 1 & 0 & 0 & 0 & 2 \\
\hline 9 & 1 & $1^{*}$ & 0 & 1 & 0 & 0 & 0 & 0 & 1 & 0 & $1 *$ & 5 \\
\hline 10 & 1 & $1^{*}$ & 0 & 1 & 0 & 0 & 0 & 0 & $1^{*}$ & 1 & $1 *$ & 6 \\
\hline 11 & 1 & $1^{*}$ & 0 & 1 & 0 & 1 & 0 & 0 & $1^{*}$ & 0 & 1 & 6 \\
\hline $\mathrm{DNP}$ & 7 & 7 & 1 & 11 & 2 & 3 & 2 & 2 & 7 & 1 & 7 & 50 \\
\hline
\end{tabular}

[Legend: $1^{*}$ : shows transitivity, DNP: Dependence Power, DRP: Driving Power, V: Variable] 
Table 8. Partition on Reachability Matrix: Interaction I

\begin{tabular}{|c|l|l|l|l|}
\hline Element P(i) & $\begin{array}{l}\text { Reachability Set: } \\
\mathrm{R}(\mathrm{Pi})\end{array}$ & Antecedent Set: A(Pi) & $\begin{array}{l}\text { Intersection Set: } \\
\mathrm{R}(\mathrm{Pi} \cap \cap \mathrm{A}(\mathrm{Pi})\end{array}$ & Level \\
\hline 1 & $1,2,4,6,9,11$ & $1,2,3,6,9,10,11$ & $1,2,6,9,11$ & \\
\hline 2 & $1,2,4,9,11$ & $1,2,3,6,9,10,11$ & $1,2,9,11$ & \\
\hline 3 & $1,2,3,4,8,9,11$ & 3 & 3 & \\
\hline 4 & 4 & $1,2,3,4,5,6,7,8,9,10,11$ & 4 & $\mathrm{I}$ \\
\hline 5 & $4,5,7$ & 5,7 & 5,7 & \\
\hline 6 & $1,2,4,6,9,11$ & $1,6,11$ & $1,6,11$ & \\
\hline 7 & $4,5,7$ & 5,7 & 5,7 & \\
\hline 8 & 4,8 & 3,8 & 8 & \\
\hline 9 & $1,2,4,9,11$ & $1,2,3,6,9,10,11$ & $1,2,9,11$ & \\
\hline 10 & $1,2,4,9,10,11$ & 10 & 10 & \\
\hline 11 & $1,2,4,6,9,11$ & $1,2,3,6,9,10,11$ & $1,2,6,9,11$ & \\
\hline
\end{tabular}

Table 9. Partition on Reachability Matrix: Interaction II

\begin{tabular}{|c|c|c|c|c|}
\hline Element P(i) & $\begin{array}{c}\text { Reachability Set: } \\
\mathrm{R}(\mathrm{Pi})\end{array}$ & Antecedent Set: A(Pi) & $\begin{array}{c}\text { Intersection Set: } \\
\mathrm{R}(\mathrm{Pi}) \cap \mathrm{A}(\mathrm{Pi})\end{array}$ & Level \\
\hline 1 & $1,2,6,9,11$ & $1,2,3,6,9,10,11$ & $1,2,6,9,11$ & II \\
\hline 2 & $1,2,9,11$ & $1,2,3,6,9,10,11$ & $1,2,9,11$ & II \\
\hline 3 & $1,2,3,8,9,11$ & 3 & 3 & \\
\hline 5 & 5,7 & 5,7 & 5,7 & II \\
\hline 6 & $1,2,6,9,11$ & $1,6,11$ & $1,6,11$ & II \\
\hline 7 & 5,7 & 5,7 & 5,7 & II \\
\hline 8 & 8 & 3,8 & $1,2,9,11$ & II \\
\hline 9 & $1,2,9,11$ & $1,2,3,6,9,10,11$ & 10 & \\
\hline 10 & $1,2,9,10,11$ & 10 & $1,2,6,9,11$ & II \\
\hline 11 & $1,2,6,9,11$ & $1,2,3,6,9,10,11$ & & \\
\hline
\end{tabular}

Table 10. Partition on Reachability Matrix: Interaction III

\begin{tabular}{|c|c|c|c|c|}
\hline Element P(i) & $\begin{array}{c}\text { Reachability Set: } \\
\mathrm{R}(\mathrm{Pi})\end{array}$ & $\begin{array}{c}\text { Antecedent Set: } \\
\mathrm{A}(\mathrm{Pi})\end{array}$ & $\begin{array}{c}\text { Intersection Set: } \\
\mathrm{R}(\mathrm{Pi}) \cap \mathrm{A}(\mathrm{Pi})\end{array}$ & Level \\
\hline 3 & 3 & 3 & 3 & III \\
\hline 6 & 6 & 6 & 6 & III \\
\hline 10 & 10 & 10 & 10 & III \\
\hline
\end{tabular}


Table 11. Canonical Form of Final Reachability Matrix

\begin{tabular}{|c|c|c|c|c|c|c|c|c|c|c|c|c|}
\hline $\mathrm{V}[\mathrm{i} / \mathrm{j}]$ & 4 & 1 & 2 & 5 & 7 & 8 & 9 & 11 & 3 & 6 & 10 & LVL \\
\hline 4 & 1 & 0 & 0 & 0 & 0 & 0 & 0 & 0 & 0 & 0 & 0 & I \\
\hline 1 & 1 & 1 & 1 & 0 & 0 & 0 & 1 & 1 & 0 & 1 & 0 & II \\
\hline 2 & 1 & 1 & 1 & 0 & 0 & 0 & 1 & 1 & 0 & 0 & 0 & II \\
\hline 5 & 1 & 0 & 0 & 1 & 1 & 0 & 0 & 0 & 0 & 0 & 0 & II \\
\hline 7 & 1 & 0 & 0 & 1 & 1 & 0 & 0 & 0 & 0 & 0 & 0 & II \\
\hline 8 & 1 & 0 & 0 & 0 & 0 & 1 & 0 & 0 & 0 & 0 & 0 & II \\
\hline 9 & 1 & 1 & 1 & 0 & 0 & 0 & 1 & 1 & 0 & 0 & 0 & II \\
\hline 11 & 1 & 1 & 1 & 0 & 0 & 0 & 1 & 1 & 0 & 1 & 0 & II \\
\hline 3 & 1 & 1 & 1 & 0 & 0 & 1 & 1 & 1 & 1 & 0 & 0 & III \\
\hline 6 & 1 & 1 & 1 & 0 & 0 & 0 & 1 & 1 & 0 & 1 & 0 & III \\
\hline 10 & 1 & 1 & 1 & 0 & 0 & 0 & 1 & 1 & 0 & 0 & 1 & III \\
\hline LVL & I & II & II & II & II & II & II & II & III & III & III & \\
\hline
\end{tabular}

[Legend: LVL: Level, V: Variable]

Table 12. Binary direct relationship matrix

\begin{tabular}{|c|c|c|c|c|c|c|c|c|c|c|c|}
\hline $\mathrm{V}[\mathrm{i} / \mathrm{j}]$ & 1 & 2 & 3 & 4 & 5 & 6 & 7 & 8 & 9 & 10 & 11 \\
\hline 1 & 0 & 1 & 0 & 1 & 0 & 0 & 0 & 0 & 1 & 0 & 1 \\
\hline 2 & 1 & 0 & 0 & 1 & 0 & 0 & 0 & 0 & 0 & 0 & 0 \\
\hline 3 & 1 & 1 & 0 & 1 & 0 & 0 & 0 & 1 & 0 & 0 & 0 \\
\hline 4 & 0 & 0 & 0 & 0 & 0 & 0 & 0 & 0 & 0 & 0 & 0 \\
\hline 5 & 0 & 0 & 0 & 1 & 0 & 0 & 1 & 0 & 0 & 0 & 0 \\
\hline 6 & 1 & 1 & 0 & 1 & 0 & 0 & 0 & 0 & 0 & 0 & 1 \\
\hline 7 & 0 & 0 & 0 & 0 & 1 & 0 & 0 & 0 & 0 & 0 & 0 \\
\hline 8 & 0 & 0 & 0 & 1 & 0 & 0 & 0 & 0 & 0 & 0 & 0 \\
\hline 9 & 1 & 0 & 0 & 1 & 0 & 0 & 0 & 0 & 0 & 0 & 0 \\
\hline 10 & 1 & 0 & 0 & 1 & 0 & 0 & 0 & 0 & 0 & 0 & 0 \\
\hline 11 & 1 & 0 & 0 & 1 & 0 & 1 & 0 & 0 & 0 & 0 & 0 \\
\hline
\end{tabular}

[Legend: 1-Quality, 2-Taste, 3-Packaging, 4-Price, 5-Promotion, 6-Organic/Inorganic, 7-Advertisement, 8Colour, 9-Nutrition, 10-Traceability, 11-Carbon Footprint]

Table 13. FDRM for variables influencing consumers' beef purchasing behaviour

\begin{tabular}{|c|c|c|c|c|c|c|c|c|c|c|c|}
\hline $\mathrm{V}[\mathrm{i} / \mathrm{j}]$ & 1 & 2 & 3 & 4 & 5 & 6 & 7 & 8 & 9 & 10 & 11 \\
\hline 1 & 0 & 0.9 & 0 & 0.7 & 0 & 0 & 0 & 0 & 0.7 & 0 & 0.5 \\
\hline 2 & 0.9 & 0 & 0 & 0.5 & 0 & 0 & 0 & 0 & 0 & 0 & 0 \\
\hline 3 & 0.5 & 0.3 & 0 & 0.5 & 0 & 0 & 0 & 0.7 & 0 & 0 & 0 \\
\hline 4 & 0 & 0 & 0 & 0 & 0 & 0 & 0 & 0 & 0 & 0 & 0 \\
\hline 5 & 0 & 0 & 0 & 0.1 & 0 & 0 & 0.1 & 0 & 0 & 0 & 0 \\
\hline 6 & 0.5 & 0.5 & 0 & 0.5 & 0 & 0 & 0 & 0 & 0 & 0 & 0.7 \\
\hline 7 & 0 & 0 & 0 & 0 & 0.1 & 0 & 0 & 0 & 0 & 0 & 0 \\
\hline 8 & 0 & 0 & 0 & 0.1 & 0 & 0 & 0 & 0 & 0 & 0 & 0 \\
\hline 9 & 0.5 & 0 & 0 & 0.5 & 0 & 0 & 0 & 0 & 0 & 0 & 0 \\
\hline 10 & 0.7 & 0 & 0 & 0.9 & 0 & 0 & 0 & 0 & 0 & 0 & 0 \\
\hline 11 & 0.5 & 0 & 0 & 0.3 & 0 & 0.7 & 0 & 0 & 0 & 0 & 0 \\
\hline
\end{tabular}

[Legend: 1-Quality, 2-Taste, 3-Packaging, 4-Price, 5-Promotion, 6-Organic/Inorganic, 7-Advertisement, 8Colour, 9-Nutrition, 10-Traceability, 11-Carbon Footprint] 
Table 14. Stabilized matrix for variables influencing consumers' beef purchasing behaviour

\begin{tabular}{|c|c|c|c|c|c|c|c|c|c|c|c|c|}
\hline $\mathrm{V}[\mathrm{i} / \mathrm{j}]$ & 1 & 2 & 3 & 4 & 5 & 6 & 7 & 8 & 9 & 10 & 11 & $\begin{array}{c}\text { Driving } \\
\text { Power }\end{array}$ \\
\hline 1 & 0.9 & 0.5 & 0 & 0.5 & 0 & 0.5 & 0 & 0 & 0.5 & 0 & 0.5 & 3.4 \\
\hline 2 & 0.5 & 0.9 & 0 & 0.7 & 0 & 0.5 & 0 & 0 & 0.7 & 0 & 0.5 & 3.8 \\
\hline 3 & 0.5 & 0.5 & 0 & 0.5 & 0 & 0.5 & 0 & 0 & 0.5 & 0 & 0.5 & 3.0 \\
\hline 4 & 0 & 0 & 0 & 0 & 0 & 0 & 0 & 0 & 0 & 0 & 0 & 0.0 \\
\hline 5 & 0 & 0 & 0 & 0 & 0.1 & 0 & 0 & 0 & 0 & 0 & 0 & 0.1 \\
\hline 6 & 0.5 & 0.5 & 0 & 0.5 & 0 & 0.7 & 0 & 0 & 0.5 & 0 & 0.5 & 3.2 \\
\hline 7 & 0 & 0 & 0 & 0.1 & 0 & 0 & 0.1 & 0 & 0 & 0 & 0 & 0.2 \\
\hline 8 & 0 & 0 & 0 & 0 & 0 & 0 & 0 & 0 & 0 & 0 & 0 & 0.0 \\
\hline 9 & 0.5 & 0.5 & 0 & 0.5 & 0 & 0.5 & 0 & 0 & 0.5 & 0 & 0.5 & 3.0 \\
\hline 10 & 0.5 & 0.7 & 0 & 0.7 & 0 & 0.5 & 0 & 0 & 0.7 & 0 & 0.5 & 3.6 \\
\hline 11 & 0.5 & 0.5 & 0 & 0.5 & 0 & 0.5 & 0 & 0 & 0.5 & 0 & 0.7 & 3.2 \\
\hline $\begin{array}{c}\text { Dependence } \\
\text { Power }\end{array}$ & 3.9 & 4.1 & 0.0 & 4.0 & 0.1 & 3.7 & 0.1 & 0.0 & 3.9 & 0.0 & 3.7 & $\mathbf{2 3 . 5}$ \\
\hline
\end{tabular}

Table 15. Effectiveness and ranking of variables

\begin{tabular}{|c|c|c|c|c|}
\hline $\mathrm{V}[\mathrm{i} / \mathrm{j}]$ & $\begin{array}{c}\text { Driving } \\
\text { Power (DR) }\end{array}$ & $\begin{array}{c}\text { Dependence } \\
\text { Power (DP) }\end{array}$ & $\begin{array}{c}\text { Effectiveness } \\
(\text { DR-DP) }\end{array}$ & Level \\
\hline 1 & 3.4 & 3.9 & -0.5 & III \\
\hline 2 & 3.8 & 4.1 & -0.3 & IV \\
\hline 3 & 3.0 & 0.0 & 3.0 & VII \\
\hline 4 & 0.0 & 4.0 & -4.0 & I \\
\hline 5 & 0.1 & 0.1 & 0.0 & V \\
\hline 6 & 3.2 & 3.7 & -0.5 & III \\
\hline 7 & 0.2 & 0.1 & 0.1 & VI \\
\hline 8 & 0.0 & 0.0 & 0.0 & V \\
\hline 9 & 3.0 & 3.9 & -0.9 & II \\
\hline 10 & 3.6 & 0.0 & 3.6 & VIII \\
\hline 11 & 3.2 & 3.7 & -0.5 & III \\
\hline
\end{tabular}




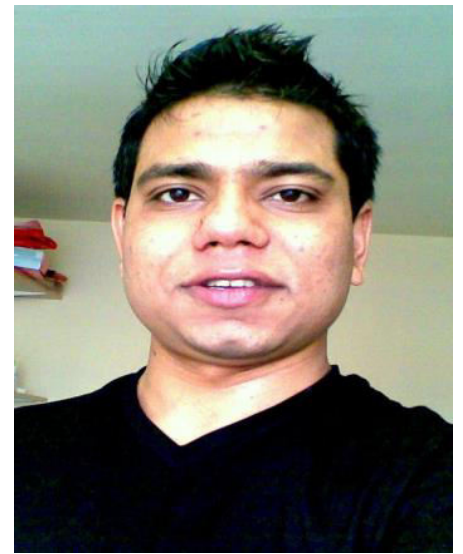

Nishikant Mishra is a Professor in Operations and Supply Chain Management at Hull University Business School, University of Hull. Prior to that he was Senior Lecturer in Operations \& Supply Chain Management and Director of Post Graduate Research at Norwich Business School, University of East Anglia, Norwich. He worked as a Senior Lecturer and Director of Research at School of Management \& Business, Aberystwyth University. He has worked on numerous consultancy projects funded by British Council, Biotechnology and Biological Sciences Research Council (BBSRC), British Academy (BA), Innovate UK, Department for Environment, Food and Rural Affairs (DEFRA), Higher Education Academy (HEA) and Meat Promotion Wales (HCC). His research articles have been published in various renowned journals of Operations Research and Operations \& Supply chain Management.

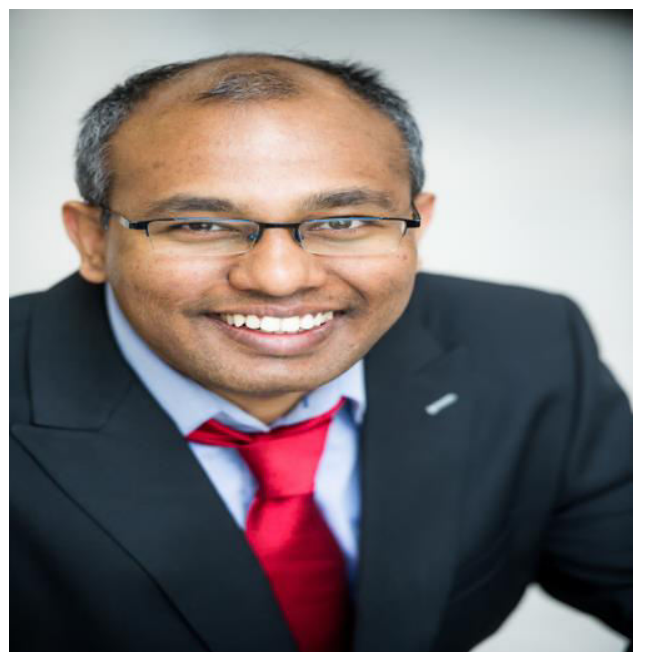

Akshit Singh is a Lecturer in Management Sciences at Alliance Manchester Business School, University of Manchester. His $\mathrm{PhD}$ is in Operations and Supply Chain Management at University of East Anglia, Norwich. He did his M.Sc. from University of Nottingham, UK and Bachelor's degree from National Institute of Technology, Kurukshetra, India. His research is close to implementation side and he is also involved in consultancy work. His research articles have been published in renowned journals such as International Journal of Production Economics, Annals of Operation Research and Robotics and Computer-Integrated Manufacturing. 


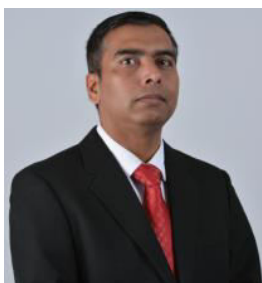

Nripendra P. Rana is an Associate Professor in the School of Management at Swansea University, UK. With an academic and professional background in Mathematics and Computer Science and with $\mathrm{PhD}$ in Information Systems, his current research interests focus primarily upon adoption of emerging and cutting edge technology, e-government, m-government, e-commerce and m-commerce systems. His work has been published in leading academic journals including European Journal of Marketing, Information Systems Frontiers, Government Information Quarterly, Production Planning \& Control, Journal of Business Research, Public Management Review and Computers in Human Behavior. He has also presented his research in some of the prominent international conferences of information systems across the world.

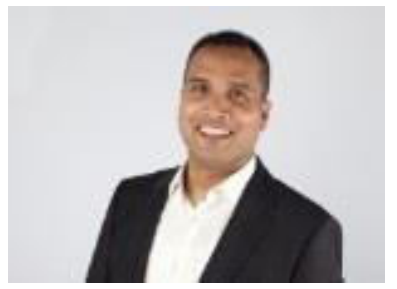

Yogesh K. Dwivedi is a Professor of Digital Marketing and Innovation, Director of the Emerging Markets Research Centre (EMaRC), and Director of Research in the School of Management at Swansea University, Wales, UK. His research interests are in the area of Information Systems (IS) including digital and social media marketing particularly in the context of emerging markets. He has published more than 250 articles in a range of leading academic journals and conferences. He has co-edited/co-authored more than 20 books; acted as co-editor of fifteen journal special issues; organised tracks, mini-tracks and panels in leading conferences; and served as programme co-chair of 2013 IFIP WG 8.6 Conference on Grand Successes and Failures in IT: Public and Private Sectors and Conference Chair of IFIP WG 6.11 I3E2016 Conference on Social Media: The Good, the Bad, and the Ugly. He is an Associate Editor of European Journal of Marketing and Government Information Quarterly and Senior Editor of Journal of Electronic Commerce Research. More information about me can be obtained from: http://www.swansea.ac.uk/staff/som/academic-staff/y.k.dwivedi/. 